\begin{abstract}
Universidade de São Paulo
Faculdade de Filosofia, Letras e Ciências Humanas

Departamento de Letras Clássicas e Vernáculas

Programa de Estudos Comparados de Literaturas de Língua Portuguesa
\end{abstract}

\title{
Eugênio Tavares: poesia e convenção romântica
}

\section{Antônio Carlos Oliveira Santos}

\section{São Paulo}




\author{
Universidade de São Paulo \\ Faculdade de Filosofia, Letras e Ciências Humanas \\ Departamento de Letras Clássicas e Vernáculas \\ Programa de Estudos Comparados de Literaturas de Língua Portuguesa
}

Eugênio Tavares: poesia e convenção romântica

Antônio Carlos Oliveira Santos

Dissertação apresentada ao Programa de Pós-

Graduação em Estudos Comparados de

Literaturas de Língua Portuguesa, do

Departamento de Letras Clássicas e

Vernáculas da Faculdade de Filosofia, Letras e

Ciências Humanas da Universidade de São

Paulo, para obtenção do título de Mestre em

Letras.

Orientador: Prof. Dr. Hélder Garmes 


\section{Nem navio}

Nem navio nem sombra de nuvem no mar para um adeus de largada...

Esta saudade infinita

É uma ilusão que se disfarça.

Grita que a dor passa!

- Saudade é voz ancorada...

A Morna...

parece que é o eco em tua alma

da voz do Mar

e da nostalgia das terras mais ao longe

que o Mar te convida,

o eco

da voz da chuva desejada,

o eco

da voz interior de nós todos, da voz da nossa tragédia sem eco! $?^{2}$

\footnotetext{
${ }^{1}$ Manuel Lopes, Crioulo e outros poemas, 1964.

2 Jorge Barbosa. Trecho do poema "Irmão", Ambiente, 1941.
} 
À minha mãe, pela sua dedicação, coragem e luta diária em prol da nossa sobrevivência.

Ao Prof. Rubens Pereira dos Santos, a quem devo o primeiro contato com a literatura caboverdiana através do seu curso Brasil e Cabo Verde: convergências.

Aos meus amigos, especialmente a Severino Bernardo dos Santos, pelo apoio, incentivo e pela sua presença nos momentos de desânimo e dificuldades. 
Agradeço:

Ao meu orientador Hélder Garmes pela generosidade e humanidade como me acolheu e conduziu esse trabalho.

A Júlio Galharte pela leitura atenta e as pertinentes sugestões que contribuíram para definição desse trabalho. 


\section{Resumo}

Eugênio Tavares (1867-1930) foi, na sua época, uma personalidade influente no cenário cultural e político caboverdiano, atuando como poeta bilíngüe e jornalista engajado, embora tenha se notabilizado apenas pela sua produção poética em crioulo (mornas). A sua poesia em língua portuguesa dispersa em periódicos e revistas ficou por muito tempo esquecida, vindo a público somente nos anos oitenta, através de uma pesquisa empreendida por Félix Monteiro, da qual um importante corpus foi publicado na revista Raízes no 17/20. Pretendemos neste trabalho traçar o roteiro biográfico do autor e fazer uma apresentação e leitura de sua poesia em língua portuguesa, ressaltando a sua militância política e a importância dessa obra no panorama literário caboverdiano desse período, como também refletir sobre a relação entre manifestações literárias e o meio social, tendo em vista as convenções estético-formais vigentes no contexto colonial finissecular e suas relações intertextuais com a obra de Eugênio Tavares.

Palavras-chave: Eugênio Tavares - Colonialismo - Literatura caboverdiana Intertextualidade. 


\begin{abstract}
Eugênio Tavares (1867-1930) was an influential personality in the political and cultural Cape verdean scenarium. He was a bilingual poet and he was also an engaged journalist, although he had been distinguished only by his poetic production in creole (mornas). His poetry in portuguese language, scattered in journals and magazines, has been forgotten for a long time. It appear only in the $80^{\text {th }}$, through a undertaken research by Félix Monteiro, who published an important corpus in the Raízes review №17/20. In this work, we intent is to draw the author's biographic route and to make a presentation and reading his poetry in portuguese language, pointing out his political militancy, the importance of the his words in the Cape verdean literary panorama, besides to reflect about the relationchip between literary manifestation and social environment, having in view the esthetic-formal conventions in the fin-de-siecle colonial context and their intertextual relations to the Eugênio Tavares words.
\end{abstract}

Keywords: Eugênio Tavares - Colonialism - Cape verdian Literature Intertextuality. 


\section{Sumário}

Resumo,

05

Abstract,

06

Introdução,

08

Capítulo I - Roteiro biográfico, 


\section{Introdução}

A maioria dos estudos sobre a literatura caboverdiana tem privilegiado autores e obras que surgiram a partir do movimento em torno da revista Claridade, enquanto a produção literária do período anterior se encontra ainda pouco estudada. Raros são os trabalhos que contemplam essa fase da história literária de Cabo Verde, quando muito, alguns manuais apresentam uma lista de autores e obras, sem qualquer aparato crítico consistente.

O percurso da literatura caboverdiana, dos primeiros escritos à Claridade, cobre um período bastante longo e complexo, tanto do ponto de vista político como social, já que o arquipélago passou por diferentes fases do processo de colonização portuguesa. Acresce a isso, os aspectos geográficos e climáticos, que, de certa forma, condicionaram a vida social e os mecanismos de exploração econômica, sem contar que a mestiçagem, tanto étnica como cultural, desempenhou um papel singular na formação da sociedade caboverdiana.

Com o advento da imprensa em Cabo Verde no último quartel do século XIX, floresceu, mesmo que de forma irregular, uma importante produção literária. Embora sem ter atingido o estatuto de sistema, essa literatura cumpriu a sua função social e possibilitou uma grande circulação literária dentro e fora da colônia. Por essa época, segundo Laranjeira (1992, p.11), a convivência entre literatura e imprensa era tão intensa a ponto de haver um forte diálogo intertextual entre esses dois gêneros de escrita. 
Os autores desse período tiveram um papel singular na vida cultural caboverdiana. Nomes como o de Pedro Cardoso (1890-1942), José Lopes (1872-1962) e Eugênio Tavares (1867-1930) foram fundamentais para o processo de dinamização da vida literária daquele arquipélago, sem contar com uma imensa massa de colaboradores anônimos que fizeram das páginas dos periódicos e revistas um espaço privilegiado para divulgação dos seus dotes literários.

Desde meados do século XIX, assistimos em Cabo Verde ao surgimento de diferentes formas de manifestações literárias. Embora ainda enraizadas na tradição cultural portuguesa, essas produções, de certa forma, já apontavam para as questões prementes do homem caboverdiano. $O$ romance $O$ escravo de José Evaristo de Almeida, lançado em 1856, na forma de folhetim, é um bom exemplo desse quadro, particularmente pela abordagem da problemática de escravidão no espaço colonial caboverdiano e pela forma de tratamento dado às personagens, todos caboverdianos (negros, mestiços e mulatos).

No que se refere às questões as convenções literárias que nortearam essa fase da literatura colonial, podemos apontar o seu caráter utilitário e a forte influência ultra-romântica como característica predominante. A maioria dessa produção tinha como finalidade o diálogo intertextual entre os autores, que eram também os leitores, exercendo sobretudo uma literatura de ocasião, associada a festas, datas comemorativas, sempre com dedicatórias aos amigos. A poesia era o gênero literário de maior destaque, principalmente a vertente lírica, já que esse, pela sua concisão e síntese e pelo seu caráter subjetivo cativava emocionalmente um público médio leitor bem mais amplo. 
Designada por Garmes (1999, p.379) de literatura de subsistência, essa fase literária cumpria uma função social bastante importante em comunicações, homenagens, elogios, etc. Como aponta Garmes em sua tese de doutoramento, nesse período a estética romântica predominava nos espaços coloniais e o fenômeno da emulação a grandes autores era uma prática muito comum entre escritores e poetas daquela época, sendo um dos fatores motivadores do processo de criação poética. Em tais contextos, segundo o autor, importava menos ser um poeta original do que ser um poeta que soubesse assemelhar-se a um poeta já consagrado.

Manuel Ferreira, um dos pioneiros do estudo da literatura caboverdiana, observa que não houve ali uma verdadeira literatura colonial, e acrescenta que "o período colonial não implica forçosamente a existência de uma literatura colonial [...], já que a colônia a partir da segunda metade do século XIX já havia adquirido feição própria" (Ferreira,1987,p.25/26). Portanto, é importante frisar que, diferentemente das outras colônias portuguesas de África, desde muito cedo Cabo Verde assistiu ao surgimento de uma pequena burguesia nativa, resultado da transferência da posse da terra e dos postos de administração para as mãos dessa elite, o que, de certa forma, provocou sua rápida ascensão e o conseqüente desenvolvimento de uma vida política e social que antecedeu em certa medida a das outras colônias da África.

Eugênio Tavares foi uma das figuras cimeiras da vida política e cultural caboverdiana dessa elite já consolidada, atuando em várias frentes. A sua colaboração jornalística teve bastante repercussão, não só pela crítica aos desmandos da administração colonial, como também, pela maestria como dominava a língua portuguesa. A sua produção literária é bastante rica e 
diversificada e cobre um leque de aspectos e gêneros, tais como: poesia em língua portuguesa, poesia em crioulo (mornas), crônicas, contos, hinos e peças teatrais.

A sua trajetória de vida, sua militância política e sua obra poética são bastante representativas para compreensão da história política e cultural de Cabo Verde. As suas vivências e andanças pelos diferentes espaços do arquipélago fizeram de Eugênio Tavares um perfeito conhecedor das mazelas do sistema colonial e do modo como estas atingiam a população caboverdiana. É a partir desse contato que o poeta percebe o quanto à situação do povo é precária e necessita de alguém que fale por ele, de uma voz que se faça ouvida.

A sua estréia como colaborador da imprensa local se deu em 1883 no Almanaque de Lembranças Luso-brasileiro, com o poema dedicado à mãe adotiva intitulado "À badinha". Apesar da pieguice e do tom sentimental, o poema foi recebido com bastante entusiasmo pelos leitores do Almanaque. Daí em diante sua participação na vida literária e jornalística caboverdiana se tornou efetiva, contribuindo, dessa forma, com a dinamização do incipiente meio cultural daquela então colônia portuguesa.

Os seus escritos jornalísticos, na grande maioria, expressam a sua indignação em relação aos desmandos da política colonial estabelecida e atestam a sua militância em prol da melhoria de vida e da situação de abandono em que se encontrava o arquipélago e a sua população menos favorecida. Desde os primeiros textos, a sua posição ideológica e a firmeza de suas convicções políticas passaram a incomodar, primeiro, os seus pares na administração pública e, depois, a elite econômica colonialista. O autor 
ocupava um posto na recebedoria pública na ilha de Brava e logo se tornou alvo de contínuas represálias e perseguições, resultando, assim, na acusação e condenação por desfalque financeiro nessa instituição e sua posterior fuga para os Estados Unidos.

A sua experiência de exílio, apesar das dificuldades e da saudade, foi muito enriquecedora. Lá, o poeta entrou em contato com diferentes correntes políticas e ideológicas, então em voga no início do século e que foram fundamentais para o seu amadurecimento intelectual, ratificando assim o seu engajamento político frente à administração e repressão colonial portuguesa. Os escritos dessa época estão evidentemente marcados por um profundo sentimento nativista.

Paralela à sua atuação jornalística, Eugênio Tavares produziu uma obra poética, como já foi observado, bastante diversificada. A sua poesia em crioulo (mornas) Ihe deu prestígio e notoriedade e é apontada pela crítica atual como precursora da caboverdianidade. No entanto, a sua poesia em língua portuguesa, vista como obra menor e continuísta da estética dominante, foi relegada ao esquecimento, só vindo a público recentemente, através de uma pesquisa empreendida por Félix Monteiro em diversos veículos da imprensa da época, tanto em Cabo Verde como em Portugal, e publicada pela revista Raízes no 17/20 sob o título de "Páginas esquecidas de Eugênio Tavares". Apesar da discutível qualidade estética, da falta de originalidade e do ranço provinciano, essa poesia se enquadra no esquema definido pelas convenções literárias dominantes no espaço colonial do último quartel do século XIX.

Situada nos fins do século XIX e inícios do século $X X$, a poesia de Eugênio Tavares é tributária de um período de intensa presença cultural 
portuguesa em Cabo Verde. Garmes (1999, p.358) aponta que durante o século XIX, Portugal foi a grande referência literária das colônias e acrescenta que o fluxo de periódicos entre a metrópole e as colônias e entre as próprias colônias desempenharam um importante papel na dinamização da emergente cena literária colonial.

A poesia produzida nesse período nas colônias portuguesas da África se caracteriza por um romantismo tardio de forte apelo sentimental e confessional. Apesar do anacronismo, essa produção reflete o convencionalismo estético predominante no imaginário coletivo da época. Antonio Candido num resumo sobre o romantismo brasileiro e que poderia também ser aplicado ao estudo das literaturas africanas desse período, observa que "esse lirismo açucarado de toque sentimental, dissolvendo a natureza na emoção e a emoção na confissão predominou de maneira alarmante na produção média dezenas e dezenas de poetas" (Candido, 2004, p.33). Ainda, segundo Garmes, "o ultraromantismo teve uma função e lugar precisos nas colônias e ganhou forças somente no final do século XIX, quando o romantismo crítico da geração de 70 e o realismo grassavam na metrópole".

A literatura portuguesa, através da sua longa tradição, foi de certa forma paradigmática para o público letrado aspirante a poeta. O contato de Eugênio Tavares com essa tradição se confirma através das versões feitas pelo poeta para o crioulo dos poemas "Engeitadinha" de João de Deus e da endecha "Bárbara, bonita escrava" de Camões e também através da dedicatória ao poeta português João de Deus que consta no seu livro Mornas, cantigas crioulas, em que o autor exprime toda sua referência e admiração e o aponta como fonte de inspiração. É possível, portanto, distinguir, mesmo de relance, 
seus possíveis diálogos com autores de diferentes fases da tradição portuguesa, tendo Camões como uma das mais freqüentes referências, embora a presença do romantismo, apesar de tardio, tenha prevalecido em sua produção desse período.

O período romântico foi um período dominado por fortes contradições teóricas e ideológicas e se prolongou, principalmente em Portugal, por quase um século, assumindo dessa forma diferentes perspectivas. Adilson Citelli, em seu livro sobre o romantismo, observa que "é necessário lembrar que o movimento romântico apresentou características diferenciais de acordo com a região onde se desenvolveu". (Citelli, 1986, p.15) Sem contar que, no romantismo, embora o diálogo intertextual tenha sido uma prática constante, valorizou-se sempre a originalidade, a diferença.

Se não podemos negar a contribuição da literatura portuguesa no processo de constituição da literatura caboverdiana, uma reflexão sobre a presença dessa tradição na poesia em língua portuguesa de Eugênio Tavares requer um trabalho bastante meticuloso, pois, apesar desse constante diálogo intertextual, não podemos perder de vista as vicissitudes individuais que cada poeta imprimiu à sua obra em busca da tão almejada originalidade. É essa a tarefa que nos propomos a cumprir nesta dissertação. 


\section{Capítulo I}

\section{Roteiro biográfico}

Nascido aos 18 de outubro de 1867, em Vila de Nova Sintra, ilha de Brava, Eugênio de Paula Tavares teve uma existência breve e bastante conturbada. Desde muito cedo o poeta passou a conviver com o problema da orfandade: primeiro a perda da mãe, em decorrência do parto, logo após o nascimento; depois a do pai, anos mais tarde, lutando contra os insurgentes na Guiné.

Sobre a sua família, segundo dados biográficos apresentados em sua página oficial na internet, ${ }^{3}$ sabemos que eram imigrantes na Guiné. $O$ pai, Francisco de Paula Tavares, natural de Santarém (Portugal), era comerciante e proprietário de terras na região de Cacheu e Geba (Guiné). A mãe, Eugênia Nozolini Roiz Tavares, era caboverdiana, natural da ilha do Fogo. O poeta era o filho caçula de uma prole de três irmãos.

Quanto ao fato do poeta ter nascido na ilha de Brava, sabe-se que, devido a problemas de saúde ocorridos durante a gravidez, sua mãe retornou à casa dos pais na ilha do Fogo para cuidados médicos, porém, com o agravamento de sua saúde, acabou se transferindo para ilha de Brava, onde havia mais recursos para tratamentos. A ilha de Brava foi uma das últimas do

\footnotetext{
${ }^{3}$ Os dados biográficos que compõem este breve biografia foram retirados da página oficial do autor (www.eugeniotavares.org) devido a escassez de material impresso. Contamos também com os textos de Corsino Fortes ("Eugênio Tavares: um construtor do humanismo caboverdiano"), de José António Nobre Marques Guimarães ("O nativismo em Eugênio Tavares"), de Manuel Ferreira (Claridade - revista de arte e letras), de Félix Monteiro (Eugênio
} 
conjunto de Sotavento a ser povoada e, devido ao clima ameno e a vasta cobertura vegetal, logo se transformou no espaço escolhido para residência oficial dos governadores e da pequena burguesia caboverdiana, resultando numa série de melhorias, como escolas, salas de leitura e uma maior concentração de médicos e outros profissionais liberais oriundos da elite. No último quartel do século XIX, a ilha de Brava foi uma importante estância de cura e repouso para toda a comunidade luso-africana da costa da Guiné e da Gâmbia; autêntico refúgio para europeus residentes no arquipélago e na vizinha costa de África. Todavia, nada disso valeu para a mãe do poeta, que não resistiu e morreu.

Com a perda do pai no campo de batalha, Eugênio Tavares foi adotado pela sua madrinha Eugênia de Vera Cruz Medina e Vasconcelos, viúva do poeta madeirense Sérvulo Medina e Vasconcelos, exilado em Cabo Verde por oposição ao regime político português, e pelo irmão José Martins de Vera Cruz, médico e influente personalidade da vida pública caboverdiana, onde atuou como presidente da câmara da ilha do Sal e de Brava, exercendo o cargo por sucessivos mandatos.

Dadas as informações referentes à sua família adotiva, depreende-se que a mesma pertencia à elite branca bravense, o que, de certa forma, era sinônimo de certos privilégios, tais como acesso a uma boa educação, a bens materiais e culturais, sem contar com a possibilidade de levar uma vida tranqüila, sem maiores reveses.

Tavares, pelos jornais...) e com as informações contidas na tese de doutoramento de Hélder Garmes e de seu artigo "O pioneirismo político e literário da Revista de Cabo Verde". 
Quanto à sua formação intelectual, é oportuno frisar que muitos autores o descrevem como autodidata. No entanto, consta que Eugênio Tavares teria cursado o ensino primário numa escola oficial, já que esse era a única forma de ensino oferecido em Brava na época. Em relação à instrução elementar, o texto do Boletim Oficial de ํㅜ 31 , de 29 de julho de 1876, apresenta as seguintes informações:

Eugênio Tavares foi examinado nas disciplinas de leitura corrente e escrita (bastardo e cursivo), subtração, multiplicação, divisão de números inteiros, gramática recitada e doutrina cristã, tendo obtido a classificação de 18 valores. $^{4}$

De acordo com a data do boletim, depreende-se que o poeta na ocasião dessa avaliação tinha nove anos de idade e que o mesmo não só freqüentou o ensino formal como também teve um desempenho escolar razoável, se considerarmos a classificação de 18 valores como numeração ordinal.

Segundo Félix Monteiro, biógrafo de Eugênio Tavares, o autor não teve a preocupação de obter qualquer certificado do ensino secundário, mas, uma vez concluída a instrução primária, teve aulas particulares das seguintes disciplinas: filosofia, com José Rodrigues Aleixo; língua latina e teologia com Padre Antônio de Sena Barcelos; e outras disciplinas, com António de Almeida Leite. Ainda sobre sua formação, Barros acrescenta que:

A formação de Eugênio Tavares fez-se no excelente ambiente em que cresceu, entre gente de cultura e

\footnotetext{
${ }^{4}$ Site oficial do autor, página da web 1 de 3.
} 
conhecimento, a cujas bibliotecas tinha acesso constante e que constituíam para ele autênticos santuários pessoais de estudo. Em todas as ilhas havia, aliás, os chamados "gabinetes de estudo" que respondiam a essa intensa ânsia de saber, a essa sede de leitura, só mitigada após os calculados períodos de espera, ao sabor do calendário de chegada dos navios, dos vapores, que chegavam a Cabo verde, trazendo jornais e livros de toda espécie, criando uma dependência-quasevício nos leitores das ilhas. Esse foi a sua escola, a sua universidade. Uma universidade em que foi aluno e professor ao mesmo tempo. (Barros, 2005, p.1)

A emergente vida cultural bravense da época era uma grande exceção em todo o além-mar português. Pelos meados do século XIX, sendo a ilha residência oficial dos governadores, como foi observado, desenvolveu-se um meio social bastante expressivo. Os funcionários do governo promoviam festas, saraus e todo tipo de atividades culturais. Todo esse surto de cultura encheu a ilha de intelectuais, poetas e escritores, contribuindo para a dinamização desse incipiente meio provinciano. Por essa época viviam na ilha os poetas Guilherme Dantas, Augusto Barreto, Maria Luísa de Sena Barcelos e José Rodrigues Aleixo, este último, considerado o filósofo da ilha de Brava, sendo que suas idéias tiveram bastante repercussão entre os estudantes desse período. Eugênio Tavares era um dos seus admiradores, quando da sua morte, teceu os seguintes comentários:

José Rodrigues Aleixo foi um grande espírito que há poucos anos se apagou nas sombrias margens do mar do Insuão [...]. O seu talento poderoso capaz de penetrar todos os problemas, de compreender todas as belezas, 
surpreendia a quantos, com faculdades de julgar, dele se aproximam. Viveu como filósofo, encerrado na amargura serena e nostálgica de uma existência primitiva, praticando a bondade com os homens, com as aves e com os animais, dentro de uma pureza de costumes que o fazia poeta não só na alma, senão nas ações. ${ }^{5}$

Por volta dos doze anos de idade, Eugênio Tavares se inicia na poesia. Segundo relatos sobre certas curiosidades da vida do autor presente em sua página na internet, o seguinte trecho ilustra o quanto a literatura fazia parte do cotidiano da vida caboverdiana: "os seus poemas corriam de casa em casa, de mão em mão, ganhando graça e notoriedade num meio onde a poesia era muito cultivada". Porém, é somente em 1883, como observamos, aos quinze anos, que o poeta estréia como colaborador no Almanaque de Lembranças Luso-Brasileiro, com o poema dedicado à sua mãe adotiva intitulado "À badinha". A recepção por parte dos amigos e familiares foi bastante calorosa, a ponto de receber elogios do escritor Luís Medina e Vasconcelos através do seguinte comentário:

São, pois, uma eloqüente promessa, repito, os seguintes versos. Há neles algumas imperfeições e durezas, que se poderiam tirar sem ferir o pensamento, mas se a forma peca aqui e ali, a idéia é bem conduzida e revela um poeta se se the proporcionarem condições para 0 estudo e quiser aproveitá-las. ${ }^{6}$

\footnotetext{
${ }^{5}$ Site oficial do autor, página da web 3 de 3.

${ }^{6}$ Idem, página da web 2 de 2.
} 
Com o êxito obtido a partir da publicação dos seus poemas na imprensa caboverdiana, o poeta resolve deixar o ambiente provinciano de Brava em busca de novas experiências para o seu crescimento pessoal. No arquipélago, a cidade de Mindelo na ilha de São Vicente era o único espaço urbano que condizia com suas expectativas. O ambiente cosmopolita de Mindelo era bastante promissor. A estratégica localização do seu porto era de fundamental importância para a navegação do atlântico sul. Uma grande quantidade de embarcações, vindas de diferentes origens, eram obrigadas a ancorar no seu porto para se abastecerem de carvão e provimentos, o que tornava Mindelo, economicamente falando, a mais importante cidade caboverdiana desse período.

É para Mindelo que Eugênio Tavares, então com 18 anos, em 1885, muda-se. Lá, o poeta emprega-se na casa comercial Union Bazar e é onde terá o primeiro contato com pessoas de diferentes nacionalidades de passagem pela cidade, principalmente com americanos, já que a empresa em que trabalhava representava os interesses dos Estados Unidos em Cabo Verde.

Nos anos em que viveu em Mindelo, o poeta estuda inglês e francês e continua a colaborar na imprensa local. Fascinado pelo cosmopolitismo, pela diversidade cultural e pelo dinamismo da cidade, passa a escrever textos sobre a cidade onde vive. Os seguintes trechos fazem parte de um artigo publicado no jornal Notícias de Cabo Verde e são bastante ilustrativos do seu entusiasmo por esse novo ambiente:

O seu valor estratégico, a instalação do cabo submarino em 1874 e a concessão de depósitos de carvão para fornecimento de navios em viagens, desenvolveu o comércio 
e gerou Mindelo, cosmopolita e linda com um modelo sóciocultural sem rival. É um espetáculo verdadeiramente original duma população flutuante que os grandes transatlânticos despejam ali, e que, desembarcando de manhã e partindo à noite, faz daquilo uma extraordinária feira cosmopolita [...]. Ruas atulhadas de gente que fala em todas as línguas, espécimes de todas as raças, exibição de todos os vestuários, de todos os costumes, de todos os tipos, desde o salero das filhas de Espanha às figuras sentimentais das misses tísicas; desde o rabicho do chinês ao punhal do corso. $^{7}$

Em 1887, após dois anos residindo em Mindelo, o poeta resolve se mudar para a ilha de Santiago. Com o apoio do seu pai adotivo, que era bastante influente no meio político colonial, consegue, em 1888, um posto na Recebedoria da Fazenda Pública do Concelho de Tarrafal.

Já como recebedor da Fazenda, com cerca de 20 anos, o poeta enfrenta pela primeira vez o poder colonial, quando se dirige ao governador para pedir a supressão de algumas multas e impostos que sobrecarregavam o povo caboverdiano. Segundo dados do site oficial do autor, enquanto recebedor, o poeta aboliu o imposto sobre a venda de palhas em Tarrafal, pois o comércio desse produto era um dos meios de sobrevivência de grande parte da população carente daquela região de Santiago.

Em Santiago acontece o batismo do poeta na africanidade. Tanto na Brava como em São Vicente, o substrato africano já se encontrava bastante diluído pelo intenso processo de mestiçagem, enquanto que em Santiago a presença negra e suas tradições culturais eram ainda muito fortes, constituindo-se ali uma sociedade muito peculiar. Como a maior e primeira ilha

\footnotetext{
${ }^{7}$ Idem, p. da web 1 de 3.
} 
do arquipélago a ser povoada, Santiago não só recebeu uma grande quantidade de africanos nos anos em que o tráfico de escravos era um negócio rentável para a cora portuguesa, como se beneficiou da mão de obra escrava como sua principal força de trabalho, diferentemente das outras ilhas, onde a exploração econômica foi feita através de pequenas propriedades sem que houvesse a necessidade de um grande contingente de escravos.

No período em que residiu na cidade de Tarrafal, Eugênio Tavares visitou várias vezes a cidade de Praia, capital administrativa de Cabo Verde, não só a trabalho, como também para participar do ambiente social e cultural que a cidade oferecia. Essas viagens Ihe proporcionaram um contato maior com as paisagens, os costumes e principalmente com a situação de carência e abandono em que vivia a maioria da população de Santiago.

Em 1890 o poeta retorna à sua ilha natal como Recebedor da Fazenda do conselho de Brava. Entusiasmado com sua volta ao convívio entre amigos e familiares e com a segurança que o emprego público the proporcionava, Eugênio Tavares casa-se D.Guiomar Leça, de quem não teve filhos. É nessa época também que o poeta se filia à maçonaria, pelas mãos do amigo Casimiro Monteiro, Grão Mestre da Maçonaria Caboverdiana.

A partir dessa fase, as colaborações de Eugênio Tavares ultrapassam os limites da imprensa local e ganham um novo viés. A experiência acumulada durante a sua estada em São Vicente e Santiago, a vivência como funcionário público e o contato com pensamento liberal maçônico foram fundamentais para o amadurecimento de suas convicções políticas e o conseqüente posicionamento combativo frente às questões sociais mais urgentes. 
Conforme estudos de Serrão et alli em a "Nova História da Expansão Portuguesa", o período que decorreu entre 1890 e 1930 (período que coincide com a atuação militante de Eugênio Tavares) conheceu algumas grandes polêmicas, marcadas pelas incompatibilidades entre certas personalidades e as autoridades, particularmente em épocas de maior crise. Ainda segundo os autores citados, a última década do século XIX e a primeira de XX corresponderam igualmente a uma afirmação de fé republicana e acrescenta:

Em Cabo Verde o republicanismo desenvolvido no final da monarquia correspondeu a uma afirmação do nacionalismo, o que também se mostra em consonância com as afirmações republicanas em geral. Algumas figuras apresentaram-se especialmente importantes no desenvolvimento deste partido, como Eugênio Tavares, na Brava. Mas as idéias disseminaram-se progressivamente por todas as ilhas, para isso contribuindo igualmente as lojas maçônicas e as organizações republicanas. (Serrão et alli, 2001,p.101)

Sentindo-se em casa, o poeta resolve se empenhar na "luta pela dignidade do povo e da pátria caboverdiana". Segundo João José Nunes, um dos seus biógrafos, apesar da inquietação da juventude e do idealismo, Eugênio Tavares estava confiante e determinado a lutar contra a situação injustiça e incúria que minavam a sua terra, mesmo sabendo das conseqüências que sua atitude poderia causar-Ihe e acrescenta que: 
[...] em plena pujança da vida, estudante do entusiasmo, Eugênio vive um sonho febril que inflama a sua alma moça e absorve todas as faculdades do seu ser moral - A Felicidade e o engrandecimento do Povo Caboverdiano cuja desgraça atroz ele atribui ao desumano abandono a que fora votado. ${ }^{8}$

Os anos que se seguiram após a sua chegada a Brava, Eugênio Tavares dedica-se ao jornalismo, tendo como foco principal as denúncias sobre a situação da administração pública colonial, exclusivamente em relação ao repasse de verbas que cada recebedoria teria direito. Alguns desses textos, principalmente os mais combativos, foram publicados na imprensa portuguesa, já que muitos desses jornais, além da maior independência editorial, não compactuavam com a ideologia colonialista portuguesa.

A sua colaboração na imprensa portuguesa, segundo Monteiro (1997, p.6), foi bastante produtiva. Do jornal português $A$ Voz Pública de maio de 1893 temos uma resposta de Francisco Pereira Batalha, editor desse veículo de imprensa, dirigida a Eugênio Tavares, que diz o seguinte: "A cartinha que mandastes fora publicada. Ficamos aguardando mais correspondências". Ainda sobre a sua participação na imprensa portuguesa, Félix Monteiro faz o seguinte comentário:

É bem provável que tenha sido Eugênio Tavares o autor de uma notícia, publicada no mesmo jornal, na qual se diz que as recebedorias em Cabo Verde não vinham sendo creditadas com regularidade pelos fundos adiantados aos administradores do conselho, isto devido ao desleixo e

\footnotetext{
${ }^{8}$ Idem, p. da web 1 de 5.
} 
incompetência dos funcionários da repartição central da Fazenda.(Monteiro,1997, p.7)

Embora seus textos denunciassem os desmandos da administração pública e a situação de abandono em que se encontrava a arquipélago, a sua relação com o atual governador, Serpa Pinto, era, até então, bastante amistosa, a ponto do autor freqüentar a sua residência e organizar os serões de mornas, poesias e serenatas. É dessa época a edição do livro Manidjas: canções, reunião de cantigas populares caboverdianas, lançado em 19 de março de 1895, a primeira publicação em língua crioula, especificamente em crioulo da ilha de Brava.

Entre 1850 e 1900 formou-se uma elite cultural na ilha de Brava, com aderentes em todas as ilhas, sobretudo na cidade de Praia na ilha de Santiago. Encabeçada por Eugênio Tavares e Loff de Vasconcelos e tendo como veículo o periódico A imprensa, a colaboração desses intelectuais foi decisiva para o surgimento da "aurora nativista em Cabo Verde" que, passando pelos claridosos, redundaria mais tarde no nacionalismo caboverdiano.

Esses intelectuais, conscientes do seu papel na sociedade, tentaram através das suas intervenções na imprensa, explicitar os problemas que atingiam a maior parte da população. A combatividade dos seus textos, principalmente no tocante à falta de alimentos e à conseqüente mortandade que assolavam as ilhas periodicamente, tomou dimensões contundentes. Os mais conservadores, ameaçados de perder seus privilégios obtidos à custa das injustiças, cedo tentaram travar qualquer tentativa de transformação da ordem social, lançando uma campanha de difamação contra os jornalistas 
comprometidos em denunciar a situação de abandono, por parte da metrópole portuguesa, em que se encontrava o arquipélago.

A final do século XIX foi marcado por uma série de medidas no sentido de reformular a administração das colônias de África, visando contornar a crise econômica oriunda da independência do Brasil e das guerras civis em torno da coroa, como também reverter a condição de subalternidade diante das nações européias depois do Ultimatum inglês. Essas mudanças tinham como objetivo tornarem essas terras mais rentáveis e a repressão era um dos meios de sujeição da população descontente.

O processo de reestruturação colonial portuguesa desse período, segundo Serrão et alli (2001, p. 30-31) tinha como objetivo proceder a ocupação efetiva dos territórios, bem como encontrar soluções para redimensionar o sistema de exploração econômica e o reconhecimento científico das possessões ultramarinas, como também modernizar a estrutura político-administrativa.

Esse período coincide com a fase mais profícua da vida intelectual de Eugênio Tavares. Corsino Fontes, no seguinte texto, traça um paralelo entre o poeta e o contexto histórico dessa época.

Segundo alguns historiadores, Eugênio Tavares nasceu e viveu numa época de profundas mudanças nas estruturas econômicas, sociais e políticas de Cabo Verde. Na verdade, entre a infância e a adolescência, é aprazado a fim da escravatura para 1878. E da adolescência à maturidade, isto é, no último quartel do século XIX, operase no arquipélago uma ruptura econômica, social e institucional (que germinava desde os meados do séc. 
XVIII), destruindo assim as estruturas básicas da sociedade caboverdiana, que tinha como características principal as relações de produção polarizadas em termos se escravos e senhores, de camponeses sem terras e morgados - o que originaria uma série de revoltas e levantamentos populares que exprimiam violentamente a decadência do sistema escravocata. (Fortes, 2002, p.7)

Já nessa altura, Eugênio Tavares é o alvo principal de forte perseguição política por parte de colegas, chefes e autoridades da elite local, devido aos ideais republicanos defendidos, tanto em palestras como na imprensa. Entrementes, ele vai se afirmando como um brilhante e fervoroso orador e jornalista, motivado por um valoroso código de ética, a serviço da sua empreitada contra os interesses da elite econômica e administrativa local.

Com a posse do governador Serpa Pinto em 1894, criam-se novas expectativas, o povo clama por mudanças, já que os administradores anteriores nada tinham feito nada para a melhoria da situação das populações mais carentes e do progresso material do arquipélago. A elite intelectual contrária à burocracia colonial reinante até então se junta ao anseio popular em apoio ao novo administrador, na esperança de avanços sociais e econômicos em prol da população em geral e das instituições.

Durante o período de administração de Serpa Pinto, Eugênio Tavares é acusado, em dois momentos diferentes, de desfalque financeiro na Recebedoria da Fazenda do Conselho de Brava. No entanto, por falta de provas e devido a influência paterna e sua relação amistosa com o então governador, os processos são arquivados. 
A posição intransigente de Eugênio Tavares contra uma minoria privilegiada incomodava, de certa forma, o alto escalão da administração colonial local, como também aqueles que levavam algum tipo de vantagem com aquela situação. As suas denúncias eram contundentes e constantes, tanto na imprensa caboverdiana, como na portuguesa. Acuada, a elite não teria outra opção a não ser neutralizar quem ousasse impedir seus interesses. Nesse contexto polarizado entre o poder colonial e o descontentamento de alguns intelectuais, há fortes razões para admitir que as acusações a Eugênio Tavares se tratavam de perseguição política, como, aliás, se depreende de uma nota confidencial de 25 de novembro de 1899 , do então secretário da Fazenda Pública de Brava, que consta na página oficial do autor na internet, que assim diz: "ele está filiado no partido dos despeitados contra o governo e nada conseguirá de bem entre o povo enquanto à testa desse povo tiver Eugênio Tavares". De Portugal, o escritor Silva Pinto, colaborador do jornal $A$ Voz Pública denunciou nesse jornal a perseguição movida contra o poeta por causa de suas idéias e atitudes contestatórias.

Com a saída do governador Serpa Pinto no final do ano de 1897, João Cesário de Lacerda retorna ao governo de Cabo Verde em 30 de janeiro de 1898 para um segundo mandato. Os pequenos avanços sociais empreendidos pelo governo anterior seriam travados pela nova administração. Dirigindo a colônia com mãos de ferro, viria reprimir e servir à causa dos conservadores. Logo após sua posse, o então governador intima Eugênio Tavares a comparecer ao palácio do governo na cidade de Praia e, numa repressão brutal, proíbe que o poeta faça qualquer menção em seus textos à fome e mortes que assolavam algumas ilhas do arquipélago. 
Para Correia (1984, p.17), desde o início da povoação, a irregularidade e a escassez de chuvas em cabo Verde foram responsáveis pela situação de penúria e fome que provocaram a morte de milhares de caboverdianos. Segundo compilação do autor supracitado, os anos em que esse fenômeno dizimou uma grande parcela da população se deram em 1889/1890 e 1894/1900, anos esses, que coincidem com as denúncias na imprensa sobre a situação de abandono em que vivia a maioria da população carente de Cabo Verde. Sendo assim, a falta de empenho dos governantes para a contenção dessas tragédias, que, de certa forma, eram do conhecimento desses há muito tempo, provocou na população geral e principalmente na elite intelectual um forte sentimento de indignação e revolta.

O aparecimento da Revista de Cabo Verde em 1899 teve bastante repercussão no meio intelectual, pois, a importância de uma imprensa livre e comprometida com as causas sociais seria fundamental para a expressão dos anseios da minoria engajada na luta contra a política do sistema colonial. Segundo Garmes (1999, p. 305), era uma folha mensal, com sede na ilha de São Vicente e tinha como diretor L. Loff e Vasconcelos, amigo e conterrâneo de Eugênio Tavares e, apesar de inteiramente caboverdiana, era impressa em Portugal como forma de burlar a situação de repressão em vigor.

Nessa revista, contrariando as pretensões da nova ordem estabelecida, Eugênio Tavares colaborou em quase todos os seus números, acirrando ainda mais os seus desafetos. No mesmo ano de lançamento Eugênio Tavares publica nos números três e quatro os seguintes textos "Pregar no deserto", "Prudências" e "A venda das colônias", em que o jornalista denuncia o descaso 
da política colonial em relação às colônias de África e principalmente a situação de abandono em que se encontrava Cabo Verde.

Entretanto, além dos textos acima citados, o autor publica no № 14, de setembro de 1899 uma matéria intitulada "Verdade", intervenção jornalística em que assumi uma postura bastante radical em nome da justiça e contra o esquema de difamação que vinha sofrendo. Nesse artigo o autor expressa todo o seu espírito combativo, por mais que essa atitude the trouxesse problemas futuros.

Verdade, sempre verdade. Verdade a todo o transe. Verdade à custa da paz do meu lar, à custa do bem dos que amo, à custa da minha própria felicidade. Verdade antes de tudo, primeiro que tudo.[...] Verdade, enfim, à custa de toda essa infamíssima mentira que se chama felicidade parasitária do ente amorfo, estúpido, hermeticamente fechado a todas as grandezas de alma, que, dentro da sua neutralidade de inútil, de covarde, de egoísta, contempla a pobreza estripada, a justiça mistificada, a virtude enxovalhada, conspurcada, - e regouga, encolhendo-se todo dentro da concha: - "Parvos! Não sabem levar a vida!" [...] Não, a verdade deve sempre ser dita e apregoada muito altas e desassombradamente". (Monteiro, 1997, p.58)

Outra intervenção jornalística e bastante polêmica de Eugênio Tavares foi publicada no ํo 17 da Revista de Cabo Verde, em dezembro de 1899, tendo o título "Não morreu". No referido texto, o autor aponta uma série de contradições da administração do atual governo, principalmente, a precária situação em que se encontrava a ilha de São Vicente. O autor condena o desvio da arrecadação desta em proveito da cidade de Praia na ilha de Santiago. Era do conhecimento 
de todos a militância de Eugênio Tavares a favor da mudança da capital de Cabo Verde para a cidade de Mindelo na ilha de São Vicente. Para o poeta, as vantagens da cidade de Mindelo em relação à cidade e Praia eram inúmeras. Dentre muitas, sua localização e prestígio, como também, a menor distância entre a metrópole e a colônia.

Em 1900, ainda na Revista de Cabo Verde, Eugênio Tavares publica uma carta aberta ao então governador Dr. Cesário de Lacerda, declarando a sua posição irredutível em defesa do povo caboverdiano. Polêmica surgida desde a proibição que esse impôs à imprensa sobre as questões referentes à fome e a situação de miséria em que se encontrava a população pobre. $\mathrm{Na}$ carta, o poeta foi bastante contundente em relação às suas convicções políticas. Citamos:

Eu exijo para o povo aquilo que de direito sei ser do povo; porque sobre o fato de the ser negado provar que the não seja devido pode muito bem o não dar hoje preparar o ter que dar amanhã. Por isso exijo, não peço. Quereis saber quem sou eu para exigir? Sou uma vontade e, por conseguinte, uma força. ${ }^{9}$

Sobre o posicionamento político defendido por Eugênio Tavares nessa revista, Garmes (2006, p.16-17) observa que "a crítica de Eugênio Tavares é bastante dura não só em relação à administração da metrópole mas também em relação ao comportamento da população caboverdina" e cita como exemplo o artigo "Prudências", publicado no terceiro exemplar da revista, em que o autor

\footnotetext{
${ }^{9}$ Idem, p. da web 2 de 2.
} 
faz uma análise da psicologia dos habitantes do arquipélago, caracterizandoos como dono de uma prudência bastante peculiar.

Eugênio Tavares assinava com pseudônimos a maioria dos seus textos jornalísticos, principalmente os de caráter militante, enviados e publicados na imprensa portuguesa, na busca de preservar a sua identidade e não se comprometer perante a administração vigente, já que era funcionário público. "Jack" era um dos pseudônimos usados com mais freqüência segundo compilação de Félix Monteiro, e que aparece em vários jornais portugueses da época, como: A Voz Pública, Marselhesa, Norte, Batalha e Correio Português, este de New Bedford, nos Estados Unidos.

No começo do ano de 1900, Eugênio Tavares é acusado, pela terceira vez, de desfalque na Recebedoria da Fazenda da Brava e, como agravantes, consta o envolvimento do autor com os ideais republicanos. Para João Nobre de Oliveira "estava em causa, igualmente, a sua posição política republicana e as idéias defendidas na imprensa" (apud Serrão et alli, 2001,p.103). Mesmo acuado, Corsino Fortes, em sua comunicação, aponta que o poeta denunciou a persistente perseguição através do livro intitulado "Um fabuloso alcance" publicado em 1900.

A terceira acusação de desfalque aconteceu logo após a derrota que o governo sofrera nas eleições das câmaras municipais dos afiliados do seu partido, graças à intervenção participativa e militante de Eugênio Tavares. O crime de ser republicano e correspondente de quatro jornais anti-monárquicos em Portugal (dois do Porto e dois de Lisboa) pesou para a sua condenação, tudo isso agravado por duas circunstâncias protagonizadas pelo poeta, como descreve Corsino Fortes no texto seguinte: 
Num jantar oficial da nomenclatura monárquica, Eugênio Tavares provocou o escândalo de fazer, na sala, apologia da sua ardente profissão de fé republicana e quando da chegada do governador o autor recusou o convite de fazer parte da equipe política, alegando que não se venderia a troco de uma paz mercantil de caráter desonesto. (Fortes, 2002, p.7)

Foram essas as acusações que pesaram contra o poeta, deflagrando no processo que durante vinte anos o impediu de ocupar qualquer posto de trabalho no governo e que trouxe transtorno à tranqüilidade de sua família. Durante a última década da monarquia, o processo nunca fora julgado, porque, segundo a opinião do juiz do supremo tribunal, Dr. Pinto Osório, o mesmo era nulo e estava atravancado de irregularidades que nunca poderia ser julgado a contento. Desse modo, Eugênio Tavares foi condenado sem qualquer julgamento. A tentativa de prisão se deu no dia 3 de maio de 1900 , quando um contingente de marinheiros desembarcaram em Brava e cercaram sua casa para levá-lo preso. No entanto, o poeta, estando no interior da ilha em companhia de amigos, foi avisado que estavam a sua procura. Logo elaborou um plano de fuga para os Estados Unidos, numa região que concentrava uma grande quantidade de emigrantes caboverdianos. O texto seguinte que consta da página oficial do poeta na internet descreve com bastante detalhe esse episódio:

Pela calada da noite do dia de Sta Cruz, nos primeiros dias de maio de 1900, um vaso de guerra enviado de Lisboa entrou na baía de Furna e desembarcou um 
contingente de marinheiros da Armada Portuguesa. Um contingente de 30 ou 40 marinheiros, perfilou no cais e marchou ao cinco quilômetros de distância, atingindo a Vila Nova Sintra e sitiando de imediato a casa do poeta Eugênio Tavares. Visavam prendê-lo e conduzi-lo a Lisboa.

Depois de uma busca infrutífera, concluíram que o poeta se encontrava em Nossa Senhora do Monte, numa festa em casa do seu compadre Nhô Lepeu. Dirigindo-se de imediato para lá, sitiaram a casa de Nhô Lepu, mas não encontraram o poeta.

Aconteceu que enquanto armavam a cilada e preparavam o cerco a casa, por entre eles passara uma mulher esgueirando-se na paisagem e desaparecendo na escuridão da noite. Essa mulher velhinha, de lenços à cabeça, saias compridas e cachimbo, à maneira da época, que desaparecera na paisagem era nem mais nem menos que Eugênio Tavares.

Decorridos alguns dias, o poeta não voltou a ser localizado nem encontrado na ilha de Brava. A 01 de Junho, pelo raiar da madrugada, Eugênio embarcou na barca B. A. ${ }^{10}$

No dia 12 de junho de 1900, o poeta embarca no porto de Furnas com destino aos Estados Unidos na barca B. A. Brayton. Depois de 29 dias de viagem, finalmente desembarca no porto de New Bedford, estado de Massachusetts. A sua chegada é descrita numa de sua crônicas de viagem publicadas em $A$ Voz de Cabo Verde, no 126 de 1914, em que o poeta faz um retrato ácido e caricato dos imigrantes caboverdianos que vêm receber parentes e amigos no cais. 
Finalmente, com 29 dias de viagem, fundeávamos á entrada do porto de New Bedford, Mass.

No dia seguinte atracou ao nosso costado um tow boat, conduzindo oficiais da alfândega e um médico.

Findo o serviço médico, o tow boat rebocou-nos para dentro e levou-nos a atracar do lado sul do Merril's Warf, onde a B. A. Brayton despejou os seus passageiros no meio duma grande barafunda de cabo-verdianos que vinham ver a chegada dos patrícios greens. Como um exame de abelhas, os nossos compatriotas zumbiam pelo cais e formigavam numa ladainha de cumprimentos, abraços, exclamações, risadas, choros.

E eram abraços de arrombar costelas, shake handes de desengonçar braços, empurrões de emborcar uma criatura, tudo à americana, tudo de molde e jeito a deslumbrar o pacóvio, o basbaque, o green que nunca vira a América. ${ }^{11}$

Em New Bedford havia já naquela época uma grande colônia de caboverdianos que desde dos meados do século XIX, com o recrutamento de pescadores para a caça a baleia, tinha se estabelecido ali e trazia constantemente amigos e familiares. Embora estivesse em meio aos conterrâneos, Eugênio Tavares não se sentia em casa e também não estava preparado para enfrentar o tipo de trabalho oferecido aos imigrantes, já que o poeta, pertencente à elite branca, nunca tinha experimentado a dureza do serviço braçal nas plantações e na construção civil. Numa outra crônica publicada no mesmo jornal supracitado, o poeta vislumbra as condições adversas que enfrentaria na América nos seguintes dizeres: "Que ia eu fazer na América! - ao tempo que eu, com minha proverbial simplicidade, lhe ia

\footnotetext{
${ }^{10}$ Idem, p. da web 1 de 3.
} 
perguntar se por erro de navegação tínhamos chegado ao inferno" (Revista Raízes no17/20, p.132). O clima, o preconceito em relação aos imigrantes, a saudade da terra natal são fatores que irão pesar na sua permanência nos Estados Unidos.

Como meio de sobrevivência, Eugênio Tavares funda em New Bedford o jornal $A$ Alvorada, considerado o primeiro veículo de comunicação da diáspora. Além de representar os interesses dos imigrantes caborverdianos na América, esse jornal servia também como espaço para o intercâmbio entre o arquipélago e a comunidade caboverdiana de New Bedford e para a troca de informações entre os próprios imigrados.

No número 2 de $A$ Alvorada, datado de 16 de agosto de 1900, Eugênio Tavares publica, na primeira página, um polêmico artigo intitulado "Autonomia". Nesse texto o autor defenderia, contra a ameaça da venda das colônias, a necessidade dos caboverdianos e dos demais povos sujeitados à colonização portuguesa de criarem um partido autônomo, tendo como palavras de ordem as seguintes expressões: "portugueses-irmãos, sim; portugueses-escravos, nunca. Havemos de ter o nosso Monroe: a África para os africanos". Apesar do caráter panfletário, o artigo já apresenta certas concepções defendidas pelo ideário pan-africanista em que o anseio de independência é a tônica dominante. Para Garmes (2006, p.17), esse artigo, de certa forma, é um manifesto implícito a favor da independência política da colônia.

Em New Bedford, Eugênio Tavares retoma a sua atividade na maçonaria e passa a fazer parte da vida social local em função dos encontros organizados por essa instituição. Durante esse período, o contato do poeta com o ideário

\footnotetext{
${ }^{11}$ Revista Raízes no 17/20, p.142.
} 
liberal dominante na sociedade americana vai consolidar sua adesão ao pensamento republicano, principalmente em relação às idéias que defendem as reformas sociais e as liberdades civis.

Duraram os dez anos de seu exílio nos Estados Unidos o poeta não deixou de colaborar com a imprensa caboverdiana e nem deixou de retornar à sua ilha natal, mesmo que clandestinamente. O poema "Triste regresso", escrito na ilha de Brava em 1900 confirma a presença do poeta em terras caboverdianas no mesmo ano em que partira para o exílio.

Muitos textos e poemas foram escritos nesse período de exílio. "Notas tonificantes", publicado nos números 17 a 24 do jornal A Liberdade, entre 1902 e 1903, ou os poemas de temática saudosista como "Minha Casa", "Exilado", "Despedida", "Partindo", "Dia de chuva" etc., são exemplos da sua constante atividade jornalística e poética, demonstrando o quanto continuava ligado a sua terra.

A sua permanência nos Estados Unidos foi, de certa forma, bastante produtiva para o aprimoramento da sua formação intelectual e de suas convicções políticas. Nesse período, Eugênio Tavares toma contato com novas e diferentes correntes políticas e ideológicas, como o republicanismo, o socialismo reformista proudhoniano e o comunismo etc., todas essas pautadas nos ideais de liberdade e solidariedade.

Para Guimarães (2005, p.2), o exílio americano contribuiu, decisivamente, para a maturação política e intelectual de Eugênio Tavares através dos múltiplos contatos que lhe facultou, tornando-o permeável às influências de diversas correntes políticas empenhadas na emancipação dos oprimidos, com destaque para o pan-africanismo. 
Com a implantação da República em Portugal em 5 de outubro de 1910, o sonho de uma nova era pairou sobre o povo caboverdiano, que, alimentados pelos ideais de liberdade e igualdade de oportunidades acreditavam que os problemas mais urgentes seriam resolvidos. Entusiasmado com essa possibilidade, Eugênio Tavares regressa de imediato à sua terra natal na esperança de obter a liberdade que tanto almejava, esperando também retomar o trabalho na administração pública. Porém, o poeta teria que esperar mais dez anos para ser absolvido do processo em que fora condenado injustamente. É oportuno esclarecer que a volta definitiva a Cabo Verde foi caucionada pela fiança dos bens de seu pai adotivo e de alguns comerciantes locais, pois sua situação financeira já não era a mesma de quando partira.

Segundo Hernandez (2002 p. 130-131), os intelectuais esperavam que o novo regime fosse destruir a pobreza, terminar com o atraso e construir os alicerces do progresso, no entanto, o que se viu foi somente uma polarização ideológica: o que os simpatizantes do republicanismo exaltavam, os monarquistas condenavam, estes últimos associando os ideais da república ao fantasma político do comunismo.

Um mês após o seu retorno, Eugênio Tavares já se encontrava na cidade da Praia para receber o primeiro governador republicano de Cabo Verde, Marinha de Campos. À semelhança do que havia acontecido no passado com o antigo governador Serpa Pinto, o poeta oferece o seu apoio e o desejo de colaborar na orientação dos destinos de Cabo Verde. Aceitando tal colaboração, o então governador oferece-Ihe os serviços da Imprensa Nacional de Cabo Verde para a publicação de um novo jornal. 
No dia 1 de março de 1911, saiu, na cidade de Praia, o primeiro número de A Voz de Cabo Verde, tendo como diretor Gustavo Carlos da Fonseca e como editor João Maria Parreira. Eugênio Tavares assumiu a função de redator chefe, embora o seu nome não figurasse nas páginas do jornal, devido à pendência do processo que corria contra ele na justiça caboverdiana. Esse número contou com duas matérias bastante distintas, uma saudando a volta de Eugênio Tavares e a outra sobre a expulsão dos funcionários públicos mais detestados. Apesar do jornal ser patrocinado pelo poder público vigente, havia uma certa independência editorial, pois, além das notícias que eram de praxe, o jornal contava com espaços reservados para literatura, traduções, denúncias e vida social. É oportuno lembrar que o romance $O$ escravo, de José Evaristo de Almeida, considerado o primeiro romance de temática caboverdiana das literaturas de língua portuguesa, publicado originalmente em Lisboa em 1856, foi reproduzido em A Voz de Cabo Verde do número 244, de 22 de maio de 1916, até o número 294, de 21 de maio de 1917, corroborando o viés nativista deste periódico.

No segundo número de $A$ Voz de Cabo Verde, publicado em 02 de março de 1911, Eugênio Tavares participa com o texto "A imprensa". O poeta faz ali uma exortação sobre o papel da imprensa na transformação social e política de uma sociedade, como também apresenta os objetivos daquele jornal e sua importância para a consolidação dos ideais de liberdade e justiça. Citemos um trecho dessa matéria:

No dia 1 do corrente mês colocou-se mais uma pedra para a grande obra da imprensa. Surgiu $A$ Voz de Cabo Verde, semanário que foi recebido, em geral, com bem patentes 
prova de regozijo e satisfação. (...) A imprensa conta mais com mais de cinco séculos de existência e pode dizer-se que foi depois de sua aparição que a sociedade lançou a semente da sua transformação intelectual e abriu o vôo a todas as ciências que formam hoje a auréola brilhante que cinge a fronte da humanidade. (...) A missão da imprensa na nossa época, livre dos obstáculos vencidos, mudou completamente de aspecto. Hoje é como um dique ao despotismo dos governos e dos governos e das autoridades quando pretendem sair da órbita da lei, o sustentáculo das liberdades adquiridas e baluarte de abrigo aos perseguidos. (Monteiro, 1997, p.83)

Segundo Guimarães (2005, p.2), a posição política de Eugênio Tavares viria a ocupar um lugar de relevo no combate nativista após a implantação da República. A partir de 1911, no contexto da defesa intransigente do ideário libertador republicano que viria a mobilizar parte da elite intelectual de Cabo Verde, Eugênio Tavares empenhar-se-ia na defesa dos direitos do seu povo, dando continuidade à luta iniciada na Revista de Cabo Verde e em A Alvorada, denunciando, sistematicamente, as contradições cada vez mais gritantes entre os princípios daquele ideário e a prática política das administrações republicanas da colônia. Tal atitude se acirra após a demissão e o regresso a Portugal, sob prisão, do governador republicano Marinha de Campos, cuja política em defesa dos caboverdianos Ihe granjeara a acusação de "nativista", termo que na época era sinônimo de conspiração contra a ordem estabelecida. Contradições que o levaria a escrever, em 20 de janeiro de 1913, no no 75 em A Voz de Cabo Verde, a propósito da dura política colonialista do governador Júdice Biker: 
Marinha de Campos inaugurou a norma republicana na administração de Cabo Verde; Biker impôs de novo, as manigâncias monárquicas. Marinha conferiu ao povo caboverdiano direitos de cidadão português; Biker cercouse de homens que saltaram sobre os ombros do enforcado povo caboverdiano com esse gesto monstruoso de carrascos dando a esticão de misericórdia. [...] Tudo isso, porém, perfeitamente natural, porque, afinal, Marinha de Campos é um republicano, e Biker não pode ainda deixar de ser realista, mas um realista nocivo, que, nesta província, prejudica o prestígio da República, pondo em acção as práticas monárquicas mais absurdas. (Monteiro, 1997, p.116)

É assim que em 1915, Eugênio Tavares se ergueria veementemente contra a tentativa de aplicação do regime de "indigenato" a Cabo Verde, prevista no projeto de Carta Orgânica elaborado pelas autoridades metropolitanas em 1914 durante o governo de Bernadino Machado, que tinha como objetivo reestruturar a administração ultramarinha tendo como princípio a descentralização financeira e o estabelecimento de normas básicas para lidar com as populações indígenas, tais como, a distinção entre civilizados e aqueles e seus referentes direitos e deveres na sociedade colonial.

No texto abaixo, publicado no no 187 do jornal $A$ Voz de Cabo Verde, intitulado "Província de Cabo Verde/ O Projeto da carta orgânica" em 1915, o autor apresenta a sua indignação contra as bases ideológicas desse projeto com os seguintes argumentos:

Indígena é, gerado ali, nascido no país. Não se entende, porém, assim o termo, no uso que dele a lei tenta fazer; porque a lei repele quanto é equívoco e dúbio, porque a lei 
é escrita para ser entendida no que diz e não para ser desfigurada no que não quis dizer. E tomando-se estas palavras - indígena - nessa acepção, nós teríamos de admitir a hipótese de, amanhã, poder um filho de sua Ex. o Sr. Governador, nascido em Cabo Verde e, logo, indígena, ser condenado pelo Sr. Administrador do concelho, por ter vindo mais alegre de uma festa, a trinta dias de trabalhos públicos, segundo a letra do art. ${ }^{\circ} 148, n^{\circ}$ 01, alínea "A" da Carta Orgânica! (Monteiro, 1997, p.170)

Desde a sua fundação em 1911, até o no 225 em 1916, o poeta participou ativamente da elaboração de $A$ Voz de Cabo Verde como redator. No entanto, apesar da sua dedicação, nesse mesmo ano deixa o seu trabalho no jornal, alegando divergências com o respectivo diretor Monteiro de Macedo. Félix Monteiro, no prefácio do livro "Eugênio Tavares pelos jornais", apresenta uma das possíveis razões do seu afastamento:

De regresso da Brava, Eugênio manifestou a sua discordância quanto á posição tomada pelo jornal, o que levou os seus fiadores a quebrar-Ihes a fiança para poder aguardar o julgamento em liberdade. Considerando inevitável a sua prisão, Eugênio entregou-se à prisão, onde passou três dias até conseguir novos fiadores. (Monteiro, 1997,p.6)

A sua prisão na cadeia civil da ilha da Brava ocorreu em 7 de novembro de 1916, ficando ali durante três dias. Da cadeia, o poeta escreve uma carta para a mãe adotiva, em que descreve o local onde se encontra preso num tom bastante irônico: 
Escrevo-te de uma nova residência, que a bondade dos homens, numa irônica expressão caricatural, andou aí durante vinte anos, a preparar-me, e para onde quis a sorte que hoje, 07 de novembro, me mudasse.

Estou num pequeno aposento, com muito pé direito, irregular, assoalho de grosso pitch-pine, alta janela fortemente gradeada e porta também defendida por formidável gradeamento.

Neste momento, enquanto entristecido o espírito, traço as primeiras linhas desta carta, a porta acaba de se fechar pesadamente, chiaram os gonzos, estrondeou o ferro nos fortes batentes, como quando se fecha um túmulo. Encontro-me emparedado.

Mãe, não é a primeira vez que um homem de honra, justo e altivo sente fechar-se sobre si as portas de uma prisão. $^{12}$

Depois de ter deixado $A$ Voz de Cabo Verde, Eugênio Tavares é sondado por outros jornais, mas prefere continuar na Brava e dedicar-se à composição de mornas e a cuidar dos seus jardins. Porém, a sua atitude militante continua ativa. É o que se nota através da sua posição contrária a solução tomada pela administração colonial vigente quanto à proibição da emigração de analfabetos para os Estados Unidos.

Numa de suas cartas endereçadas a D. Alexandre D'Almeida, datada de 10 de junho de 1918, intitulada de "Noli me tangere", ${ }^{13}$ Eugênio Tavares defende a emigração dos caboverdianos para os Estados Unidos, argumentando que esses, além de enviarem recursos para os seus familiares, também adquiriam novos conhecimentos e que se convertia em bem-estar para

\footnotetext{
${ }^{12}$ www.eugeniotavares.org
} 
todo o arquipélago. Em contrapartida, condenava a emigração forçada para as roças de São Tome, porque, segundo o autor, o contratado era condenado, disfarçadamente, a uma nova forma de escravidão.

Na visão de Hernandez (2005, p.529), as emigrações espontâneas eram fundamentais, já que dinamizavam a economia, possibilitando, dentre outros benefícios, a aquisição de terras, a aplicação em investimentos públicos e o equilíbrio da balança de pagamentos. Acrescenta a constituição peculiar da população caboverdiana fez dali um território diferenciado pela metrópole portuguesa, em virtude do fato de as ilhas terem sido marcadas por processos de "assimilação" bastante longos e eficazes, em particular nos centros urbanos, ficando livre da aplicação do código do "indigenato". ${ }^{14}$

Depois de 21 anos da abertura do processo contra Eugênio Tavares, finalmente, em 1921, o poeta é julgado e absorvido. Livre das acusações que Ihe causaram tantos sofrimentos, o autor regressa definitivamente à Brava em 1922. Escreve para garantir sua sobrevivência e dedica-se à educação e ao cultivo de flores, mas é, sobretudo, através da composição de mornas que se realiza.

Nesses anos, Eugênio Tavares participou ativamente da vida social da ilha da Brava como agitador cultural. Com os amigos, tendo a frente Hermano de Pina, fundou a Escola Governador Guedes Vaz, a Troupe Musical Bravense

\footnotetext{
13 A expressão "Noli me tangere" foi usada por Eugênio Tavares devido a relação entre o conteúdo de sua carta com a temática nacionalista do livro de José Rizal que tinha o mesmo título e que é considerado o primeiro romance filipino.

${ }^{14} \mathrm{O}$ código do indigenato é de 1899 e tinha como princípio regulamentar o trabalho dos indígenas nas colônias portuguesas da África. Considerava-se indígena os indivíduos de raça negra ou descendente que não tinha alcançado ainda, nos termos do artigo 256 do Estatuto, o uso pleno dos direitos civis e políticos conferidos aos cidadãos portugueses, ou seja, todos aqueles que não fossem assimilados.
} 
e implantou a disciplina de educação física, que até então não constava nos currículos da época, escreve contos e monta peças teatrais.

A sua extensa colaboração jornalística foi recolhida e organizada, como observamos, por Félix Monteiro e publicada em 1997 sob o título de "Eugênio Tavares pelos jornais". De acordo com a compilação feita pelo autor concluímos que o período que se estende entre 1897 e 1929 foi de intensa participação de Eugênio Tavares na imprensa caboverdiana, tendo-se o jornal A Voz de Cabo Verde como principal veículo de divulgação dos seus artigos.

As suas cartas e postais enviados dos Estados Unidos entre 1900 e 1910 para a esposa, mãe, sobrinha e diversos amigos são fundamentais para o estudo e interpretação do seu pensamento e da história da época. Nessas cartas, segundo os dados da sua páginas oficial na internet, "Eugênio Tavares aparece na sua dimensão de pensador e de fazedor de opinião e as utiliza como libelo doutrinário". Todo esse material foi lançado pelo próprio autor em cinco edições com o título de "Cartas caboverdianas".

Além da composição de mornas, a sua produção poética em língua portuguesa é bastante expressiva, tanto do ponto de vista formal, quanto temático, embora a sua qualidade estética seja discutível. A importância dessa obra é relevante para compreensão do contexto histórico-social e sua relações com as convenções literárias em vigência nessa época.

Como já foi aqui remarcado, a sua produção literária cobre um vasto leque de gêneros. O poeta também dedicou à criação narrativa e teatral. Manuel Ferreira em seu manual sobre as literaturas de língua portuguesa faz um inventário dessas produções. Das obras narrativas, apresentamos os títulos e as datas em que foram publicados: "A força d'amor: vida na América" 
(1912); "A virgem e os meninos mortos de fome" (1913); "A barca Katleen, drama da pesca da baleia"(1913); "Maldito telegrama" (1914); "Crioulas" (1914) etc., todos esses textos foram publicados em A Voz de Cabo Verde.

Sobre sua produção teatral, temos notícia de três peças: $A$ peçonha (primeiro folhetim literário publicado em $A$ Voz de Cabo Verde); A ceia da parelha; Filhos que salvam. Dos contos, constam também três títulos: "Samar"; "Por causa de um casamento"; "Guida" (publicado no jornal A Alvorada). Nada sabemos, porém, a respeito dos enredos dessas obras.

Como republicano, o poeta defendeu a causa da liberdade religiosa, exclusivamente em relação à igreja Nazarena, que na época vinha incomodando a cúpula católica devido a sua capacidade de arrebanhar uma grande quantidade de fiéis. Para Eugênio Tavares, o protestantismo trouxera uma nova concepção de prática religiosa e isso agradou um grande público. $\mathrm{Na}$ época, o poeta chegou até mesmo a compor hinos para serem cantados nas celebrações, mas, ao que tudo indica, a sua adesão se limitou apenas aos aspectos musicais.

Nos últimos anos da República, apesar do declínio do nativismo, Eugênio Tavares continuaria a pugnar pelos direitos dos seus concidadãos, empenhando-se na defesa da língua e da identidade cultural caboverdianas, como demonstra o artigo "Língua de pretos", que faria publicar no oㅜ 11 do jornal O Manduco, em janeiro de 1924. Nesse artigo, o poeta defende o crioulo como a verdadeira língua dos caboverdianos. Para ele, o dialeto caboverdiano constitui num verdadeiro documento "glotológico" de uma das mais interessantes transformações da língua portuguesa. Além de tratar das questões referentes ao processo de mestiçagem ocorrida no arquipélago, o 
poeta critica a denominação "língua de pretos", argumentando que seria melhor chamá-la de "língua de brancos mal ensinada a pretos", e termina o artigo dignificando o crioulo como uma das transformações mais felizes da língua portuguesa entre os povos coloniais.

Em 1927 o governador Guedes Vaz foi à ilha de Brava, numa visita de cortesia e desagravo a Eugênio Tavares, apresentar um pedido formal de desculpas pelo sofrimento causado pelas acusações caluniosas efetuadas pelos governos anteriores. Nesse encontro, convidou-o para uma homenagem nacional junto com os poetas José Lopes, Pedro Cardoso e Januário Leite, em Mindelo, na ilha de São Vicente.

Pouco tempo depois de ser homenageado em São Vicente, o poeta recebe a visita do intelectual português José Osório de Oliveira, que foi à Brava especificamente para encontrá-lo, já que era um grande admirador das suas mornas. A este Eugênio Tavares entregou um importante corpus das sua composições em crioulo para a confecção de um livro. No entanto, o poeta não viveu a tempo de ver publicado Mornas, cantigas crioulas, editado em Portugal no mês de fevereiro de 1932.

Sobre a edição desse livro, Manuel Ferreira tece o seguinte comentário:

Esta edição, nesse tempo, e quanto a nós, constituiu-se num gesto audacioso. José Osório de Oliveira, na sua boa intenção e na sua não menos ingenuidade, acreditou que a publicação daquele livro despertaria um interesse especial por parte dos portugueses ou que os portugueses iriam impressionar-se com as mornas de Eugênio Tavares tal qual ele se impressionou. (Ferreira, 1986, p.23) 
No entanto, essa publicação não teve a recepção esperada pelo editor, restando ainda exemplares à venda na livraria José Rodrigues na década de 70. Mas, segundo Manuel Ferreira, o gesto audacioso de José Evaristo de Almeida contribuiu para dar aos portugueses uma idéia da alma crioula.

A morte de Eugênio Tavares aos 63 anos, em 1 de junho de 1930, o impediu de ver a edição dessa obra, que para o autor e para a cultura caboveriana tinha um sentido muito especial, pois sintetizava os dois elementos mais importantes da identidade cultural local, ou seja, a morna e o crioulo.

A sua morte foi recebida com muitos pesares pela população do Cabo Verde. Um clima de total consternação tomou conta de sua ilha natal. A repercussão de sua obra na alma caboverdiana continua viva até os dias de hoje, tamanha era a sua identificação com os anseios populares. Manuel Ferreira sintetiza neste trecho certas características sua personalidade política e literária:

Autodidata, raízes profundas no lirismo popular, Eugênio Tavares investiu, como se disse, grande parte das suas disponibilidades artísticas numa poética em crioulo. Profundamente dado à vida, não raro em tensão e contestação, os apelos sociais e políticos da época caboverdiana que lhe coube viver são marcas intensas da sua poesia sem que, no entanto, o realismo social ou o realismo crítico caboverdiano lhe tenham despertado o seu estro. Os apelos que referimos são de caráter ideológico, inscrevem -se na poesia e na prosa política, no quadro do inconformismo e de certo modo no reformismo. (Ferreira, 1986, p.35) 
Félix Monteiro, seu biógrafo, pesquisador e organizador da sua obra, apresenta no prefácio do livro "Eugênio Tavares pelos jornais" um relato sobre as dificuldades encontradas em relação à pesquisa e recolha do material sobre o poeta. O autor aponta, entre outras razões, "o fato desolador e lastimável de já não existirem vestígios sequer de tais publicações nas nossas bibliotecas" e acrescenta que as informações que constam sobre a atividade jornalística e literária de Eugênio Tavares foram transcritas na sua maioria da Revista de Cabo Verde e do jornal A Voz de Cabo Verde. Embora muito desses jornais e revistas tenha desaparecido, o material recolhido é bastante relevante para compreendermos a dimensão da sua obra e sua importância no processo de construção da história social e cultural caboverdiana no contexto finissecular.

Eugênio Tavares se tornou uma das personalidades mais populares da vida social e cultural caboverdiana, primeiro, pela sua militância em favor das causas mais prementes do povo do arquipélago, segundo, pela difusão das suas mornas (cantigas crioulas) por todas as classes sociais e ilhas. Para concluir este longo capítulo, mais uma vez citemos Manuel Ferreira, que tece elogios ao poeta neste breve comentário, ressaltando a sua importância como cidadão e poeta:

Eugênio Tavares brilhou em Cabo Verde como grande estrela, sobretudo pela imediata fama que as suas mornas the granjearam e essa fama ainda se mantém. Jornalista, homem progressista, guindou-se a notável altura, devido o seu talento de poeta e é considerado como um dos que dotaram a língua de Cabo verde - o crioulo - de novos recursos artísticos, especialmente em mornas celebradas pelo povo, como "Hora di bai". (Ferreira, 1987, p.30) 



\section{Capítulo II}

\section{Manifestações literárias, imprensa e meio social}

É consenso entre os historiadores da literatura caboverdiana tomar como ponto de partida da vida literária de Cabo Verde o ano de 1842, quando se

introduz a imprensa naquele arquipélago. É que somente a partir daí que tornou-se possível à impressão de livros e periódicos. Os pioneiros foram as folhas oficiais de informação, que incluíam também alguns textos com pretensões literárias, mas é somente nos anos 70, 80 e 90 do século XIX, com o surto da imprensa livre, que se delineia um cenário literário significativo.

Lembremos que, antes do estabelecimento da imprensa, as comunidades locais, constituídas de europeus e nativos (brancos, negros e mestiços), encontravam-se quase integralmente isoladas da metrópole no que concerne à escrita literária. Após um primeiro momento de forte atividade missionária no século XVI e em parte no século XVII, as comunidades coloniais foram culturalmente abandonadas pela metrópole portuguesa. Aos que ali se encontravam estabelecidos, restaram a busca da sobrevivência material. Os investimentos educacionais eram precários e pouco sistemáticos, sem jamais recuperar o desempenho das missões quinhentistas, que buscaram a 
conversão de almas utilizando-se da literatura e das artes como meio de dogmatização.

Após a instalação da imprensa, iniciou-se um novo momento de valorização da escrita, da literatura e das artes, que se viu diante da tarefa de reinstaurar a valor de tais atividades nas colônias. No entanto, é necessário ter em vista que a essa produção literária não era delegado o poder de avaliar e levar aos píncaros da glória senão aquele que fizesse exatamente o que se reconhecia como boa literatura, isto é, naquele momento, meados do século XIX, a literatura convencional romântica.

O aparecimento do já referido romance O escravo, de José Evaristo de Almeida, em 1856 é considerado um marco entre as produções literárias desse período e é tido como obra emblemática, pois reflete as condições sociais e culturais do contexto colonial caboverdiano. Tanto Portugal (1999, p.72), como Laranjeira (1995, p.180), na tentativa de periodização histórica, estendem essa primeira fase literária caboverdiana até 1926, com o lançamento do livro de poemas Jardim das Hespérides de Pedro Cardoso.

Segundo Manuel Ferreira, não houve em Cabo Verde uma verdadeira literatura colonial e acrescenta que, "a colônia, a partir da segunda metade do século XIX, havia já adquirido feição própria, resultado da transferência da posse da terra e dos postos da Administração para as mãos da burguesia caboverdiana, mestiça, branca e negra" e para justificar sua opinião, o autor cita como exemplo o romance $O$ escravo, apresentando o seguinte comentário:

Uma das virtudes desse texto está em que quase totalidade das personagens são caboverdianas (negros, mestiços, mulatos). E o espaço é o da escravidão, abrindo-se a nós 
hoje para a compreensão de um mundo longínquo no tempo, a permitir uma perspectiva social diacrônica de longo alcance. (...) Ora, esse texto de José Evaristo de Almeida, na verdade, vem de encontro daquilo que nos andava, até há pouco, no domínio da suspeição: não ter havido em Cabo Verde uma literatura colonial. (Ferreira, 1987,p.25/26)

Chamado de período da "iniciação", essa fase, apesar da profícua atividade literária, ainda não se configuraria num sistema literário, mas sim num conjunto de manifestações literárias isoladas. De acordo com o esquema proposto por Antonio Candido (1997, p.23), a distinção entre manifestações literárias e literatura propriamente dita se daria a partir "da existência de um conjunto de produtores literários, um conjunto de receptores formando os diferentes tipos de público, sem os quais a obra não vive, e um mecanismo transmissor, (de modo geral, uma linguagem, traduzida em estilos), que liga uns a outros".

Para Candido, as fases iniciais da formação literária, de um modo geral, são sempre pautadas pela falta de organicidade, "dada à imaturidade do meio, que dificulta a formação dos grupos, a elaboração de uma linguagem própria e o interesse pelas obras. No entanto, segundo o autor, "isto não impede que surjam obras de valor - seja por força da inspiração individual, seja pela influência de outras literaturas".

Se compararmos os autores dessa fase com os do segundo período, ou seja, de 1926 em diante, verificamos que os primeiros não tinham um projeto literário definido, publicavam seus poemas ou narrativas aleatoriamente, sem qualquer preocupação em ordená-las a partir de uma dada especificidade, 
diferentemente daqueles do período conhecido como "Hesperitano", que já esboçam em suas obras uma relação entre os anseios nativistas e o imaginário cultural popular, numa tentativa de busca identitária.

Para Duarte (1997, p.183), o primeiro período literário caboverdiano foi de imitação dos autores europeus, e acrescenta que a literatura escrita surgiu de forma quase abrupta, por via culta, com a emergência de uma elite formada dentro dos cânones da cultura portuguesa, tendo como base as influências literárias européias em língua portuguesa, língua que até então fora quase estranha à prática social.

A poesia em língua portuguesa de Eugênio Tavares, publicada nos periódicos e revistas dos anos entre 1883 a 1914 se enquadra no panorama literário desse primeiro período, pois, além da falta de sistematização e regularidade estético-temáticas, sua obra compartilha com o grosso da produção média da época, em que perduram a mesma função utilitarista de cunho individualista e sentimental bem ao gosto do público receptor médio. A falta de organicidade é tanta que muitos desses autores não tiveram o interesse em reunir suas produções em livros, como é o caso do poeta aqui estudado.

Dentro dessa perspectiva, podemos adequar o seguinte comentário de Candido (1985, p.74) sobre a relação entre escritor e público no período de formação da literatura brasileira à literatura caboverdiana. Para o autor, o escritor e o poeta, numa determinada sociedade, não é apenas o indivíduo capaz de exprimir a sua originalidade, mas alguém desempenhando um papel social, ocupando uma posição relativa ao seu grupo social e correspondendo a 
certas expectativas dos leitores e editores, caracterizando um diálogo mais ou menos vivo entre criador e público.

Contudo, essa fase da literatura de Cabo Verde é bastante exemplar e o seu relativo pioneirismo em relação às outras colônias se deve não só aos talentos individuais que emergiram nessa corrente de produções literárias, mas principalmente às condições sócio-históricas que o meio insular proporcionou para o surgimento dessas ricas e variadas vertentes de manifestações culturais.

A sociedade caboverdiana do período colonial, mas precisamente, dos meados do século XIX até o advento do movimento em torno da revista Claridade apresentou certas peculiaridades que a diferenciava das demais colônias portuguesas da época. Muitos estudiosos apontam o intenso processo de mestiçagem e aculturação como fatores preponderantes da constituição de sua formação, o que, de certa forma, veio contribuir para o desenvolvimento de uma vida social muito peculiar. A disseminação da instrução escolar pelos diferentes espaços do arquipélago e o surto da imprensa livre nos fins do século XIX tiveram também um importante papel na efetivação do incipiente meio cultural daquelas ilhas.

Em relação à constituição da sociedade caboverdiana, Carreira (1984, p.139) observa que, das décadas finais do século XIX aos primeiros anos do XX, a diferença entre classes era demarcada muito mais pelo índice de riquezas e privilégios sociais do que verdadeiramente pela cor da pele. Segundo dados estatísticos apresentados pelo autor, na virada do século, $60 \%$ da população era composta de mestiços, o que corrobora a importância da mestiçagem como especificidade da sociedade cobeverdiana. 
Mariano (1991, p.67) afirma que quem lançou os alicerces da sociedade crioula foi a homem crioulo, o próprio caboverdiano: o negro, o mulado e o branco já aculturados. Segundo o autor, quanto ao português da metrópole, "sem contaminações tropicais", ido para o arquipélago depois do surto colonizador inicial, só havia um caminho: adaptar-se aos estilos novos que começavam "madrugando" em Cabo Verde.

Cronologicamente, segundo Hamilton (2000, p.18), o primeiro movimento cultural-literário da África Lusófona surgiu em Cabo Verde. Para o autor, os padrões históricos da colonização do arquipélago, com a instalação relativamente cedo de instituições educacionais, principalmente do seminárioLiceu, foram fundamentais para o surgimento de diferentes formas de manifestações culturais.

Num estudo sobre o surgimento das literaturas escritas da África, Margarido (1980,p.109-110) aponta três condições prévias para o aparecimento de manifestações literárias nos meados do século XIX. Para o autor, o primeiro fator foi a eliminação do tráfico de escravos, ainda que o trabalho escravo continuasse a ser uma prática corrente e legalizada no mundo português pela legislação de 1899. Segundo, a introdução da tipografia. Para ele, isso permitiu a criação das imprensas nacionais, por vezes muito combativas. E, por último, a criação dos Boletins Oficiais, seguido pouco depois pela publicação de um número importante de jornais, mais freqüentemente como expressão política e cultural dos colonos, mas portadores também de vozes autóctones.

O papel da educação, embora contemplasse apenas um reduzido grupo de privilegiados, foi fundamental no processo de dinamização da vida literária 
caboverdiana a partir dos meados do século XIX, pois sua implantação possibilitou o surgimento de um meio social em que a aspiração literária era um bem cultural almejado por grande parte dessa pequena parcela de letrados.

Sobre o interesse do caboverdiano em relação à educação e sobre o sucesso desta no meio social da época, citamos o comentário do Pe. Antônio Vieira quando da sua estada em Cabo Verde no século XVII:

Há aqui clérigos e cônegos tão negros como azeviche; mas tão compostos, tão auctorisados, tão doutos, tão grandes músicos , tão discretos e bem morigerados, que podem fazer inveja aos que lá vemos nas nossas cathedraes. (apud Hamilton,1984, p.119)

Segundo Garmes (1999, p.76), em 1462, as ilhas de Cabo verde já dispunham de um vigário e de um coadjutor. A diocese seria criada somente em 1533, sob a direção de franciscanos e em 1592 começou a funcionar um seminário. Sobre a dinamização da educação em Cabo Verde, acrescentamos do seguinte comentário de Hélder Garmes.

No século XIX, a primeira escola laica apareceu em 1817, na Praia. No início, porém, da década de 1840 já tínhamos 12 escolas oficiais distribuídas por diversas ilhas. A partir de 1845, com a reforma da instrução pública em Portugal, cresceu o número de escolas em cabo Verde. Em 1848, fundou-se a escola principal da ilha de Brava, sendo legislado que, em todas as escolas do arquipélago, só seria permitido o uso do português, sendo terminantemente proibido o emprego do dialeto crioulo. (Garmes, 1999, p.76) 
A proliferação de escolas em Cabo Verde no decorrer no século XIX foi bastante significativa. Conforme dados apresentados por Garmes (idem, p.296): "em 1870, registraram 43 escolas e em 1861 se deu a abertura do Liceu Nacional, estabelecido nos paços do conselho na cidade de Praia, integrando-se em 1866 ao Seminário-Liceu". Portanto, no final do século XIX, Cabo Verde contava com uma estrutura escolar razoável, se confrontada com aquelas existentes no restante das colônias portuguesas na África.

Uma estatística relativa ao ano de 1930 encontra uma população de 144.382 indivíduos compreendendo mestiços, negros e brancos. Neste mesmo ano, os valores de freqüência escolar davam uma percentagem de $64 \%$ ao mestiço, uma mais baixa ao negro, $30 \%$, ficando os restantes $6 \%$ para o branco. Um apanhado estatístico mais largo, entre 1889/1890 e 1907/1908, mostra que, nesta viragem do século, as vantagens de proporção, na freqüência escolar, pertenciam ao branco, $3 \%$ da população, com $6 \%$ de alunos, e para o negro, 33\% da população com $39 \%$ de alunos. Porém, em finais deste período, o branco subiu pouco, de $6 \%$ para $9 \%$, enquanto o mestiço subiu de $55 \%$ para $65 \%$ a custa de uma quebra de alunos negros de 39\% para 26\%. (Carvalho, apud Garmes, 1999, p.79)"

Através desses dados estatísticos constatamos a ascensão intelectual dos mestiços em Cabo Verde, como também, a evolução quantitativa de um público letrado, embora o analfabetismo nessa época atingisse $90 \%$ da população em geral. Segundo Laranjeira (1995, p.20), o analfabetismo devia-se à política portuguesa de criar uma elite muito restrita de assimilados para servirem no setor terciário, ao mesmo tempo que as populações estavam 
entregues a si próprias, sem acesso ao seu auto-conhecimento ou, no pior dos casos, a massa de analfabetos era usada como mão-de-obra escrava e barata.

O seminário-Liceu de São Nicolau foi, durante esse período, a principal instituição educacional de nível secundário do ultramar português. Estudantes de outras colônias próximas, como da Guiné e de São Tomé. Boa parte da elite intelectual saiu de suas cadeiras, principalmente aquela que ocuparia os quadros públicos não só de Cabo Verde, como também das demais colônias portuguesas da África.

Mariano (1991, p.58/59) nota que desse Seminário, fundado em 1866, saíram não só eclesiásticos, mas gerações sucessivas de leigos, com uma cultura clássica notável. Essas gerações espalharam-se pelos serviços públicos quase sem concorrência, já que a pobreza das ilhas sempre repeliu a entrada sistemática de elementos metropolitanos.

Outro fato diretamente relacionado à educação e à leitura ocorreu em 1871, quando da inauguração da Biblioteca e do Museu Nacionais de Cabo Verde, na cidade de Praia e 1881 criou-se a Biblioteca Pública da llha de S. Vicente, transformando assim, o cenário colonial bastante promissor em termos de letramento e leitura.

Conforme Russel G. Hamilton em seu manual sobre as literaturas de língua portuguesa, o desenvolvimento da educação se deve à existência de instituições européias estabelecidas, relativamente cedo em Santiago e nas ilhas de barlavento e acrescenta:

Juntamente com as escolas, que contribuíram para um índice de alfabetizados relativamente alto, embora não tão alto nem democrático quanto tem sido proclamado pela 
Metrópole e por membros da elite caboverdiana, fundaramse também, a partir da segunda metade do século XIX, sociedades dramáticas, grêmios culturais e literários e,naturalmente, uma imprensa controlada por elementos da elite indígena. É claro que estas instituições eram tão européias quanto aquelas em que foram modeladas. Assim, na década de 1890, os alunos do seminário de São Nicolau (fundado em 1866) estudavam literatura clássica, retórica e latim. (Hamilton, 1984, p119)

Embora o papel da educação seja indiscutível na formação da elite intelectual caboverdina, não podemos renegar a importância da imprensa e das associações culturais nesse cenário.

As contribuições das associações para o desenvolvimento da sociedade caboverdiana são inegáveis, tanto em relação aos aspectos culturais e educacionais, como também em relação à organização de grupos de intelectuais preocupados com os problemas enfrentados pela população carente.

Segundo Gabriel Mariano, a presença das associações recreativas e culturais a partir da segunda metade do século XIX foram decisivas para a manutenção das tradições culturais e intelectuais em Cabo Verde. Segundo pesquisa do autor, a primeira associação foi criada em 1853 na vila de Praia, e desta data até 1892 fundaram-se cerca de treze dessas instituições em Santiago, nas seguintes datas:

Em 1853 surgiram: - sociedade recreativa Esperança; 1864 - Sociedade Filarmônica Juventude; 1867 - Grêmio Promotor; Sociedade Dramática do Teatro Africano; Associação Igualdade; 1868 - Sociedade Dramática do 
Teatro de D. Maria Pia de Sabóia; 1869 - Sociedade de Leitura; 1876 - Sociedade Euterpe; 1880 - Sociedade Recreativa clube União; Associação Literária Grêmio Caboverdiano; 1886 - Associação dos Artistas da Cidade da Praia; 1892 - Sociedade Recreativa Praiense. Em relação às outras ilhas, o autor cita o Clube Fraternidade no Fogo, em 1883; a Sociedade Recreativa Fraternidade em São Vicente, no anos de 1888; a Filarmônica de Artistas Mindelenses, em 1889; o Clube Luso-Britânico, em 1895, também na ilha de São Vicente; uma sociedade denominada "llustração Africana", na ilha do sal; uma sociedade instrutiva recreativa na ilha de São Nicolau, com a denominação "Fraternidade", em 1874. (Mariano, 1991,p57)

Em 1867 funda-se na vila de Ribeira Grande na ilha de Santiago a Associação lgualdade e de acordo com o seu estatuto, o seu objetivo era "o estudo recreativo e profícuo da arte dramática". Nessa época a associação promove espetáculos teatrais. Sabe-se da encenação das comédias, "Uma Entalação" e "O ferro velho", em benefício do teatro D. Maria pia de Sabóia.

De acordo com o "Boletim Oficial" ํㅡㄹ, de 15 de Junho de 1867, a associação denominada Grêmio Promotor publica o seu estatuto, onde se lê: "a presente associação tem como fins, combater a ignorância e a ociosidade dos desvalidos da sorte, facilitando-Ihes trabalho e ensino e promover a extinção da escravidão por meio de filantropia". Conforme Mariano (1991, p.58) cerca de dois meses após a sua fundação conseguia o Grêmio a alforria de cinco escravos.

Note-se que além das suas contribuições culturais essas associações tiveram outras atribuições. Os membros dessas entidades tinham não só uma 
preocupação assistencialista, como também o interesse em desenvolver ações de caráter político. Muitas dessas entidades, durante o período repressivo, se disfarçavam de grêmios recreativos para articularem reuniões de caráter reivindicativo e de oposição ao regime colonialista. Cerca de 42 instituições de caráter cultural, religioso, humanitário, social ou profissional são fundadas no arquipélago até o ano de 1908.

Para Serrão et alli (2001, p.134), além do caráter filantrópico dessas associações, muitas tinham um fim específico. Como aponta os autores, num primeiro momento, essas estavam ligadas à fundação de bandas de música e como exemplo citam o modelo da Filarmônica de Artistas Mindelenses, que tocava em praça pública. No segundo momento, a atenção das associações concentrou-se preferentemente no aspecto desportivo, como é o caso do Grêmio Sportivo Caboverdiano, no Mindelo em 1916, sendo que posteriormente surgiram o Sport Club da Praia, depois o Club Sportivo Mindelense, a União Desportiva de Cabo Verde etc., todos dedicados à cultura esportiva.

Ainda sobre a vida cultural dessa época, os autores citados destacam os espetáculos teatrais, muito comuns nas cidades de Praia e Mindelo e apontam que:

Também se podia assistir a espetáculos no Teatro Africano, na Praia, quer por actores locais quer vindos de outros pontos (em 1913 e 1919, por exemplo, representou aí Joaquina Vélez). Desde de 1909 que esta casa apresentava também cinema. Estabelecimentos similares eram o Salão Pathé, igualmente na Praia, o Theatro Éden 
Park, em São Vicente. Na Ribeira Grande a Biblioteca Escola tinha um cinematógrafo. (Mariano,1991, p.59)

A imprensa foi indiscutivelmente o principal fator que condicionou 0 surgimento de manifestações literárias nas colônias portuguesas. Como já foi observado anteriormente, a educação desempenhou um papel importante na criação de um público leitor, porém, somente com a circulação de periódicos e revistas é que foi possível a divulgação das produções literárias dos aspirantes a literatos desse período.

Pires Laranjeira destaca a importância e as funções que a imprensa desempenhou nas colônias portuguesas a partir da sua fundação, no seguinte comentário:

É, pois, através dos jornais que os letrados fazem a aprendizagem da escrita, vendo os seus escritos em letra de forma, assim modelando a própria concepção de intervenção literária, que ficaria marcada por essa prática intrínseca de concretude e explicitude, a no ser quando toda a sorte de preciosismos (saídos do ulta-romantismo, parnasianismo e decadentismo) tomava conta da efusidade lírica. Esse desígnio jornalístico - ou melhor, de comunicação social, à letra - marcaria decisivamente os escritores de África, que quase sempre assistiram á divulgação dos seus textos através de compilações e antologias, antes de os poderem ver estampados em livro, um objeto a que poucas vezes tinham acesso, por dificuldades de vária ordem (censura, perseguição, pobreza, desleixo, dispersão, etc., que foram aumentando em crescendo até à independência). (Laranjeira,1995, p.20) 
O surto da imprensa em Cabo Verde no último quartel do século XIX foi, de certa forma, bastante produtivo, tanto para o intercâmbio entre as ilhas do arquipélago, como para a circulação de novas idéias e divulgação das produções literárias no contexto geral da colonização portuguesa.

Conforme Garmes (1999, p.283), a instalação da imprensa em Cabo Verde se deu em 1842 e em 24 de agosto desse mesmo ano saiu o primeiro número do Boletim Oficial do Governo de Cabo Verde. O papel da imprensa foi fundamental no processo de veiculação das manifestações literárias e reivindicativas, desaguando, posteriormente, na luta pela afirmação identitária.

Nessa primeira fase da imprensa em Cabo Verde, além do boletim, que era um órgão oficial, surgem paralelamente os primeiros veículos não oficiais, como o "Independente" (1878), "O Correio de Cabo Verde" (1879), "Eco de Cabo Verde" (1880), "A imprensa" (1881), "Almanach Luso-Africano" (1894) e a "Revista de Cabo Verde (1899).

De acordo com os estudos de Hélder Garmes sobre a imprensa dessa época, todos esses jornais apresentavam uma seção sobre cultura com destaque para a literatura e esse era um espaço aberto à colaboração do público leitor em geral. Sobre o boletim, o autor relata que até 21 de agosto de 1851, este cumpriu um papel bastante profícuo em termos literários, publicando, além de crônicas e relatos de viagens, literatura ficcional e poesia. As matérias de caráter literário e cultural tinham lugares privilegiados, contrariando o perfil tradicional de um boletim, marcado pelo caráter legislativo e relatorial.

Entre 1847 e 1850, o Boletim Official de Cabo Verde apresentou uma seção literária digna de qualquer periódico 
lisboeta, estampando duas longas narrativas folhetinescas de autoria de Sévulo de Paula Medina e Vasconcelos: "A bella virgem do Mondego ou as duas victimas" e "Um filho chorado - romance". Ambas pautavam-se por um romantismo exacerbado, ao modo de Camilo Castelo Branco, sem, contudo, a mordacidade e a perspicácia dele. Eram histórias redigidas integralmente dentro do ultraromantismo, passadas em Portugal, sendo que seu valor residia no fato de serem publicadas originalmente em Cabo Verde, ainda que nada tivessem a ver com a realidade cabo-verdiana. (Garmes, 1999, p.289)

Sobre a relação entre literatura e imprensa nesse período, destacamos o papel dos periódicos; "Amanach Luso-Africano", "A Imprensa" e da "Revista de Cabo Verde" no processo de divulgação e dinamização da cena literária entre os diferentes espaços do arquipélago.

O "Almanach", segundo Garmes, era uma espécie de sociedade que, além do seu caráter jornalístico, patrocinava concursos literários. A literatura ficcional e em versos publicados nesse veículo era naturalmente de ocasião (relacionada muitas vezes a datas, eventos, acontecimentos, comemorações etc.) e marcadamente convencional, correspondendo ao virtual gosto do leitor.

Já a "Imprensa" se destacou pelas publicações de diversos textos, principalmente os de caráter nativista, como narrativas ficcionais em que as tramas eram ambientadas no próprio arquipélago e também por ter reunido um grupo importante de jornalistas e literatos do calibre de Eugênio Tavares, José Lopes da Silva e Antônio Januário Leite etc.

Podemos considerar, de acordo com Garmes (2006, p.230), que a geração da Revista de Cabo Verde também procurou aproximar a proposta de uma nova ordem político-cultural com uma nova forma literária, na medida que 
valorizou a literatura local em detrimento da literatura da metrópole. "Tal procedimento era, contextualmente, um grande passo para a afirmação de uma identidade literária local. Além disso, e com um sentido radical de unir transformação social e literária, deu dignidade literária e cultural ao crioulo".

Consta que de 1884 a 1925 mais de 25 jornais circularam pelo arquipélago, embora, em certos períodos, por motivos econômicos ou políticos, muitos deles tiveram uma existência efêmera. Para Portugal (1999, p.72), a função e o valor da imprensa reveste-se de grande importância para a história de Cabo Verde, com especial relevo no desenvolvimento cultural e literário. Apesar dos inúmeros problemas enfrentados pela imprensa desde a sua introdução, a cena jornalística em Cabo Verde foi muito produtiva. Nas primeiras décadas do novecentos assistimos à circulação de um número importante de jornais, como: A Liberdade (1902), A Opinião (1903), Cabo Verde (1907), A Voz de Cabo Verde (1911), O Independente (1911), O Progresso (1912), O Mindelense (1913), O Futuro de Cabo Verde (1913), A Defesa (1913), O Popular (1914), O Cabo-verdiano (1918), Cabo Verde (1920), A Acção (1921), A Verdade (1922), O Manduco (1923) e Vasco da Gama (1924).

Hernandez (2002, p.120) aponta que em Cabo Verde, na segunda metade do século XIX, com a veiculação dos primeiros jornais, tornou-se possível a propagação do clima de insatisfação que animava a luta ideológica até o começo do século XX. A maior parte da exígua literatura a que se tem acesso atesta que na virada do século um pequeno grupo de intelectuais caboverdianos demonstra acentuada simpatia pela corrente liberal, potencialmente hegemônica no ocidente. 
Por essa época, segundo Laranjeira (1992, p.11), a "crônica e o planfeto de cariz doutrinário e político faziam gênero. $O$ folhetim narrativo agradava na colônia e obrigava à reedição na imprensa da metrópole colonizadora". Africanos, portugueses e brasileiros publicavam nos espaços comuns dos almanaques, boletins, revistas e folhetos.

Uma das características do meio social dessa época era, como já observamos, os freqüentes saraus e encontros, sempre regados à música e literatura. Qualquer evento era motivo para a declamação de poemas e leitura de narrativas, principalmente as de forte apelo romântico como relata Gabriel Mariano no seu livro Cultura Caboverdiana.

Como índice de vida familiar e intelectual nos fins do século XIX, registe-se o que contam os mais velhos acerca de reuniões íntimas bastante freqüentes, em que se ouvia música e se recitavam poemas de românticos portugueses e brasileiros; reuniões em que participavam, além dos intelectuais do tempo (mulatos e brancos), senhoras com apenas o segundo grau de instrução primária, que se entregavam ao gosto de recitar longos poemas inteiros, como "Noivado do Sepulcro", "A Judia" ou o "Dizem que há gozos no correr dos anos", de Casimiro de Abreu, e que levavam até ao convívio diário cenas romanescas de Júlio Dinis, de Camilo, etc., como por exemplo aquela passagem das Pupilas do Senhor Reitor: "Toma arsênico, filho, porque não hás de tomar arsênico?", que adquiriu foros de estribilho nas bocas das moças da época. (Mariano, 1991, p.58)

Sobre as manifestações literárias desse período é importante ressaltar o papel da imprensa na formação tanto do público leitor, como do público 
produtor de obras literárias. Essa literatura, segundo Hélder Garmes, desdobrase em várias frentes, pois muitos caboverdianos deixaram as ilhas para se estabelecer em Portugal. Enquanto alguns publicaram seus textos na metrópole, muitos dos que ficaram escreveram bastante, mas jamais publicaram.

Segundo o autor, os literatos que se destacaram na cena literária dessa época foram: Eduardo Balsemão, Sérvulo de Paula Medina e Vasconcelos, Custódio José Duarte, Luís Medina, Guilherme Dantas, Adelina Cabral Varella, A. J. d'Oliveira Bouça, Luis Loff Nogueira, Porfírio P. Tavares, José Lopes da Silva, A. Vasconcelos Sarmento, Eugênio de Paula Tavares, Antônio Januário Leite, Gestrudes Ferreira Lima e Antônio Manuel da Costa Teixeira.

Desse grupo, chamamos a atenção para as contribuições de Eugênio Tavares, Antônio Januário Leite, José Lopes da Silva e Pedro Cardoso pelo papel que tiveram na imprensa dessa época, atuando tanto como literatos, como jornalistas engajados na defesa das causas mais prementes do homem caboverdiano.

Pedro Cardoso, José Lopes, Eugênio Tavares, nesse aspecto, nessa vertente colonial, foram o produto acabado de contexto histórico, social, cultural, ideológico, e esse contexto no natural cumprimento da sua função produziu uma consciência. Seríamos os últimos a condená-los. O seu discurso era pacífico, até o aparecimento da nova fase - a de 30 - que instaurou uma nova ordem literária. Não é demais afirmar que esses homens, segundo as perspectiva que a época permitia, não traíram o seu povo nem a sua pátria. Mas todos quiseram e se esforçaram por dignificar 0 seu país. (Ferreira, 1986, p. 70-71) 
Pires Laranjeira ressalta que "os homens que escrevem são os mesmos que pensam e que politicam". Para muitos desses intelectuais, a militância política tinha mais relevância que o fazer literário e suas atuações jornalísticas tiveram bastante repercussão, não só pelo teor nativista, mas como instrumento de denúncia e reivindicação dos direitos elementares da grande massa de excluídos sem vez e sem voz.

No que diz respeito às características da literatura que preencheram os cadernos ilustrados dessa fase áurea da imprensa livre, podemos acrescentar que todos os poetas mantinham a rima final e uma grande percentagem deles usava como forma privilegiada a redondilha maior. Muitos escritores caboverdianos, nessa altura, não reivindicavam uma especificidade africana, se bem que fosse inequívoco o seu sentido de caboverdianidade.

Poderíamos citar, segundo Hamilton (2000, p.16), vários exemplos de intelectuais oriundos das camadas nativas das colônias nos fins do século XIX e começos do XX. Basta frisar que os intelectuais negros e mestiços, através dos seus jornais, associações fraternais e atividades culturais, prepararam o terreno para os movimentos literários que surgiriam entre os anos de 1930 e 1940 nas colônias da África.

Para concluir, nada melhor do que o se guinte texto de Antonio Candido que pode ser aplicado também à literatura caboverdiana quanto às questões relativas às produções e aos literatos desse período:

Com efeito, o escritor se habituou a produzir para públicos simpáticos, mas restritos, e a contar com a aprovação dos grupos dirigentes, igualmente reduzidos. Ora, esta circunstância, ligada à esmagadora maioria de iletrados 
que ainda hoje caracteriza o país, nunca lhe permitiu diálogo efetivo com a massa, ou com um público de leitores suficientemente vasto para substituir o apoio e o estímulo de pequenas elites. Ao mesmo tempo, a pobreza cultural destas nunca permitiu a formação de uma literatura complexa, de qualidade rara, salvo as devidas exceções. Elite literária, no Brasil [e também em Cabo Verde nesse período ${ }^{15}$ ] significou, não refinamento de gosto, mas apenas capacidade de interessar-se pelas letras. (Candido, 1985, p.85)

Tomada em seu conjunto, a mais evidente característica das manifestações literárias nessa fase de iniciação em Cabo Verde é a de ser uma produção convencional e conservadora, estética e politicamente falando, se tomada da perspectiva do que então se produzia na Europa naquele momento. Cumpria uma função bastante convencional em comemorações, homenagens, elogios etc. Não chegava a construir ou mesmo trabalhar uma identidade própria nos moldes em que faziam os portugueses e outros europeus, ainda que já esboçasse, em pontuadas manifestações nativistas, algumas representações literárias daquele espaço colonial. Procurava, tanto no seu aspecto utilitário, como em seu incipiente aspecto nativista, um lugar em que pudesse fazer sentido.

\footnotetext{
${ }^{15}$ Grifos nossos.
} 


\section{Capítulo III}

\section{Poesia e convenção romântica}

Situada nos fins do século XIX e começos do XX, a poesia de Eugênio Tavares é tributária de um período de intensa presença cultural portuguesa em Cabo Verde. Como ficou demonstrado no capítulo anterior, Portugal foi a grande referência literária dos caboverdianos, que moldaram suas instituições de ensino, suas associações, suas bibliotecas, sua imprensa, toda sua vida letrada, enfim, nos parâmetros advindos da metrópole. Diante desse contexto, é natural que também no âmbito do texto, do estilo literário, os caboverdianos acompanhassem o que era produzido em Portugal.

A poesia produzida nesse período nas colônias portuguesas da África se caracteriza por um forte apelo sentimental e confessional de cunho ultraromântico. Apesar do anacronismo, essa produção reflete o convencionalismo estético dominante do imaginário coletivo da época.

A presença da literatura portuguesa no contexto caboverdiano através da sua tradição secular cumpriu um papel relevante como paradigma para um público letrado aspirante a escritor. No que concerne a Eugênio Tavares, já nos referimos às versões para a língua caboverdiana feitas por ele dos poemas "Engeitadinha" de João de Deus e "Bárbara, bonita escrava" de Camões, além da dedicatória a João de Deus.

Mas o texto que maior tributo faz ao poeta português seu contemporâneo encontra-se no seu livro Mornas, cantigas crioulas. Tendo como título "Ao altíssimo espírito de João de Deus", o texto (dedicatória) que se segue é 
bastante ilustrativo para entendermos a relação entre um poeta aspirante e o poeta modelar, como bem caracteriza o processo de "emulação", muito comum, como já comentamos, no contexto colonial durante o romantismo.

Pois que o plectro de João de Deus, luzeiro do ibero lirismo, é a asa das nossas inspirações, e é o fogo sagrado de nossos altares; dos que cantam e dos que sofrem; dos que amam e dos que ardem no culto da Raça glorificada na serena majestade do Gênio; penso que, de mal, poucos me alvejarão porque ouso abrir este pequeno florilégio de cantigas crioulas com a chave de oiro duma versão, no dialecto que se fala nesta ilha Brava, da "Engeitadinha" do grande lírico.

De joelhos sobre o moimento ${ }^{16}$ de João de Deus (menos para ser visto que para me sentir no dever do meu culto), deponho este pobre rosário de canções, que, em verdade, à secura do papel, pouco trazem do aroma e da cor com que desabrocham, como um sangue vivo de cravos e de rosas, nas bocas das raparigas da minha terra, que com tanto amor - única honra minha - as decoram e cantam. (Tavares, 1969, p.25)

Podemos relacionar, grosso modo, emulação a imitação, o que era uma prática também muito comum entre os academicistas do século XVIII em relação aos autores clássicos. Durante o romantismo o processo emulativo passou a ser feito entre os autores contemporâneos, pertencentes a uma mesma escola literária. Neste caso, os românticos periféricos tinham como modelo seus pares dos centros de irradiação estética, ou seja, os portugueses prestavam referência aos franceses e os literatos das colônias aos

\footnotetext{
${ }^{16} \mathrm{O}$ vocábulo foi transcrito com a mesma grafia que se encontra no texto do autor em seu livro "Mornas, cantigas crioulas", edição da Liga dos Amigos de Cabo Verde de 1969.
} 
portugueses. No entanto, tal procedimento não pode ser considerado como algo exclusivo do período romântico, já que em diversas épocas outros autores foram emulados ainda em vida. Todavia, é no romantismo que, apesar do postulado da originalidade do gênio como critério maior para determinar a qualidade de uma obra literária, tal prática ganhou uma dimensão jamais vista em períodos anteriores.

A emulação aos grandes mestres portugueses era, acima de tudo, uma afirmação de conhecimento, tanto do repertório, como da capacidade de bem escrever. Experimentar, tentar, arriscar eram atitudes pouco presentes nas atividades literárias das colônias; como de resto, em grande parte da literatura romântica produzida na Europa e no mundo, apesar da grande valor dado à originalidade.

Foram, portanto, os autores e os textos portugueses que serviram como referências modelares - formal, temática e estilística - à literatura romântica produzida nas colônias. Também as traduções cumpriram tal papel, pois, apesar da barreira lingüística, circulavam ali tramas, temas e uma certa forma de poetar, narrar e descrever que ultrapassam e que podiam migrar de um sistema literário lingüístico para o outro.

Segundo Garmes (1999, p.345), o resultado de todo esse quadro de referências literárias foi uma literatura que efetivamente seguia o que poderíamos chamar de cartilha romântica e, portanto, justificava em parte o adjetivo "convencional".

Entendemos como cartilha romântica o conjunto de recursos métricos, palavras, expressões e, principalmente, imagens e idéias que passaram a constituir uma espécie de gramática dessa corrente literária desde que o 
romantismo ganhou o estatuto de literatura consagrada. Tal cartilha difundia os preceitos elementares do romantismo, como a valorização da beleza natural, o culto à mulher como anjo ou demônio, a supremacia do sentimento e da subjetividade em detrimento da realidade física e material, o culto ao cristianismo e seus mitos, o culto à pátria, a valorização da cor e das tradições locais, enfim, aquele conjunto de preceitos que caracterizam o romantismo em sentido amplo. Estes dogmas, que nos grandes autores românticos tinham gerado obras verdadeiramente complexas, passaram a tomar uma forma esquemática, reduzida e rasa. Aparecem então a pieguice, a loquacidade, o automatismo de imagens, o uso abusivo de diminutivos, a frouxidão do verso, o desleixo da métrica e gramática, como assinala Candido (1964, v.2: 198) ao comentar a banalização dos padrões românticos na poesia brasileira.

Conforme Garmes (1999,p.342), se pensarmos não mais cronologicamente, mas sim nas tendências um tanto genéricas que perpassam a historiografia romântica, como o romantismo histórico, o romantismo noir, o romantismo cristão, o romantismo nativista, o romantismo revolucionário, o romantismo ingênuo e sentimental, ainda que tais vertentes se sobreponham e sejam de difícil definição, podemos considerar que se destacam na produção das colônias o romantismo cristão e o romantismo ingênuo e sentimental, embora a produção de certos autores já apresente um incipiente nativismo.

Apesar da constante tendência de pensarmos a literatura romântica nas colônias portuguesas como resultado de uma imposição monolítica, isto é, a literatura chegaria de Portugal pronta e os literatos das colônias apenas a emulariam em bloco, não era exatamente desse modo que tudo se passava. Havia alguma possibilidade de escolha. Os diversos autores românticos 
portugueses, representando diversas correntes românticas distintas, forneciam um leque de opções aos incipientes meios literários coloniais. Ao privilegiar a segunda geração de românticos portugueses, os literatos das colônias fizeram sentir sua capacidade de distinguir e emular adequadamente os temas mais recorrentes da literatura romântica européia na expressão que mais força romântica Ihes delegava.

Sobre as referências da tradição literária portuguesa na poesia de Eugênio Tavares podemos apontar que esse diálogo foi bastante produtivo e perpassa diferentes escolas e autores, constituindo um cabedal de apropriações e nuances, desde as mais contundentes àquelas que se aparecem mais sutilmente, embora a maioria dessas se apresentem traduzidas por um forte viés romântico.

\section{Percurso poético}

O ponto de partida de sua produção poética se dá com a publicação do poema À badinha", de 1884, e daí até o final de sua vida o poeta manteve uma constante atividade literária. Traçar o percurso poético dessa produção não significa, sistematicamente, determinar o seu processo evolutivo, no entanto é natural que suas criações apresentem características que denunciem o seu amadurecimento intelectual e literário no decorrer de sua existência.

Sua poesia ficou durante muito tempo relegada ao esquecimento, sem contar que muitos poemas se perderam, devido à falta de recursos materiais e empenho em conservar essas publicações. Uma parte desse pequeno corpus que compõe esse estudo foi retirada do livro, Mornas, cantigas crioulas, edição 
lançada pela Liga dos Amigos de Cabo Verde em 1969, em Luanda, da qual consta um adendo com uma pequena amostra de poemas em língua portuguesa. Já a outra parte, foi retirada, como anteriormente observado, da revista Raízes no 17/20, que, sob o título de "Páginas Esquecidas de Eugênio Tavares", do qual foram reunidos a maior parte dos seus poemas em língua portuguesa, graças ao incansável esforço empreendido por Félix Monteiro no sentido de resgatar essa obra para o conhecimento das futuras gerações, tendo em vista a sua importância no conjunto da obra poética de Eugênio Tavares.

O percurso de sua poesia em língua portuguesa segue paralelamente a diferentes fases de sua vida. Sendo assim, esses poemas se configuram em uma seqüência pautada pelos fatos que condicionaram a sua criação.

Podemos ler a poesia de Eugênio Tavares a partir dos diferentes condicionamentos que repercutiram nas suas vivências. Seguindo essa perspectiva, arrolamos os poemas seguindo a ordem em que essas circunstâncias foram decisivas na sua criação.

Em relação às datas que esses poemas foram escritos, só temos conhecimentos de quatro deles: "À badinha" primeiro poema de Eugênio Tavares publicado no Alamanach de Lembranças Luso-Brasileiro em 1884 aos quinze anos de idade; o poema "Esperança" editado na Revista de Cabo Verde no mês de abril de 1899; "O exilado" escrito em Fairhaven, EUA, em 1900; "Triste Regresso" escrito na Brava em 1900; e "Crioulas", segundo dados de Manuel Ferreira, foi publicado em 1914. 
Portanto, a seqüência dos poemas que compõe esse estudo obedece, na impossibilidade de uma determinação cronológica, a ordem dos acontecimentos que marcaram essas criações.

Dois fatos bastante decisivos marcaram profundamente a vida do autor. O primeiro, a campanha de difamação através de acusações levianas sobre desfalques na recebedoria da fazenda impetrada pelos seus pares da administração colonial. O segundo, o exílio nos Estados Unidos a partir dos meados de 1900 e que duraram 10 anos. Sendo assim, podemos organizá-los na seguinte ordem: poemas anteriores aos problemas enfrentados pelo autor, poemas escritos durante período em que se deu a perseguição política e poemas do exílio, ficando a parte os poemas "Crioulas" e "Hinos".

De acordo com esses critérios, agrupamos na primeira fase de sua produção os seguintes poemas: "À badinha", "Meu bem", "Canções aladas", "Camponesa formosa", "Canção do mar", "A valsa "e "Os miseráveis". Enquanto que da segunda fase, ou seja, a época em que as acusações pesaram sobre a sua vida, temos: "Esperança", "A minha estrela", "A dor", "Realidade: sonho horrível", "Não sei", "A morte", "Deus" e "Sempre adorada". E para finalizar, apontamos os poemas do período do exílio: "Despedida", "Partindo", "Exilado", "Triste regresso", "Dia de chuva", "O sonho", "Minha casa", "Daria a vida", "Saudade", e "Não me pertence".

Os poemas: "Crioulas" e "Hinos" fazem parte de um período posterior, ou seja, da maturidade do autor. Um explora os aspectos da mestiçagem étnica e cultural de Cabo Verde sob um viés religioso; o outro, aborda as questões políticas defendidas pelo ideário republicano, do qual o poeta era militante. 
Os poemas da fase em que se deu a perseguição contra o autor expressam um forte sentimento de impotência e descrença na justiça humana e divina. As acusações injustas que pesaram sobre o poeta causaram-Ihe muitos desabores e sofrimentos, o que o levaria a apresentar uma atitude de descrença em relação ao ser humano e à sociedade. Esses textos foram escritos nos últimos anos do século XIX e traduzem as suas angústias e lamentações.

Os escritos que compõem o grupo de poemas do exílio se caracterizam por um forte apelo saudosista. A junção entre o saudosismo e o descontentamento em relação o espaço do desterro resultou numa série de textos expressamente sentimentais em que a amargura e o pessimismo em são a tônica dominante.

\section{Entre diálogos e convenções}

Na poesia de Eugênio Tavares podemos aferir um diálogo bastante produtivo com a tradição literária portuguesa, tanto em relação às nuances individuais autorais como em relação ao imaginário cultural de forma geral. A sua poesia, apesar do anacronismo, desenvolveu as diferentes temáticas que compuseram o panorama literário ocidental, tendo o romantismo como principal referência.

O poema "Camponesa formosa" é um bom exemplo da relação da sua obra com as diferentes facetas da tradição poética portuguesa. 


\section{Camponesa formosa}

Oh camponesa formosa

De olhos gentis de matar Vem clarear a tristeza

Com a luz do teu olhar

Tu que descalça e risonha,

Corres por montes e vales

Deixa que eu siga os teus passos

Deixa que eu fuja aos meus males

Mostra-me o trilho florido

Que ao teu afecto conduz,

Dá-me o teu braço amável

Sou um ceguinho sem luz

Oh camponesa formosa

De olhos gentis de matar

Dá-me o teu braço e partamos

Vamos cantar e sonhar

Oh camponesa formosa

De olhos gentis de matar

Vem clarear-me a tristeza

Com a luz do teu olhar

Leva-me assim pelas mãos

Lá pelos remansos da serra

Tira-me tu da cidade

Que me entristece e aterra 
Hei de adorar-te e servir-te

Como Jacob a Raquel

Hei de morrer a teus pés

Como o teu cão mais fiel.

Esse poema resgata uma série de elementos dos poemas camonianos "Descalça vai pera a fonte" e de "Sete anos de pastor Jacó servia", embora transfira esses elementos para o contexto pastoril arcádico, o que, de certa forma, são aspectos ainda presentes na passagem do arcadismo para o romantismo. É interessante frisar que o romantismo português se inicia com a publicação do poema Camões de Garret e que nessa primeira fase ainda permanecem atuantes alguns valores neoclássicos.

Prestemos atenção ao vocabulário e versos do poema "Camponesa formosa" e seu explícito diálogo com os poemas de Camões citados anteriormente, como: "Oh camponesa formosa/ De olhos gentis de matar/ Tu que descalça e risonha/ Corres por montes e vales". Os dois poemas descrevem a figura feminina tendo em vista a graça e a beleza com que transita pelo espaço pastoril. Nos versos seguintes, a convergência é também bastante visível, no entanto, atentemos para a releitura do poema camoniano através de uma sutil vassalagem amorosa de viés romântico que remonta às cantigas medievais presente no verso final, muito comum da poesia trovadoresca: "Hei de adorar-te e servir-te/ Como Jocob a Raquel/ Hei de morrer a teus pés/ Como o teu cão mais fiel".

Outro aspecto muito peculiar do romantismo português e que percorre a poesia de Eugênio Tavares é a temática do exílio, que é de certa forma, um sentimento inerente ao eu-lírico romântico, ou seja, o estado de espírito 
atormentado e incompreendido em busca um lugar sempre distante daquele em que se encontra.

$\mathrm{Na}$ cultura portuguesa, o tema do desterro foi desenvolvido a partir do século XV e foi o leitmotiv de grande parte dos autores, de Camões a Fernando Pessoa. Com o romantismo, o tema teria um dos momentos mais fecundos, quer no plano da experiência pessoal dos escritores exilados pelos conflitos políticos que assolaram Portugal, quer no plano simbólico.

Edward Said (2001, p.49) apresenta no seu texto sobre exílio várias questões que tratam da situação de deslocamento territorial e existencial que envolve as pessoas exiladas. Para o autor, "o exílio é uma fratura incurável entre o ser humano e o seu lugar natal", e que há uma forte relação entre a condição de exilado e o sentimento nacionalista e acrescenta que "o nacionalismo é uma declaração de pertencer a um lugar, a um povo e a uma herança cultural.

Assim como Eugênio Tavares, Alexandre Herculano, entre os escritores da primeira geração romântica, toma o tema do exílio como o cerne da sua poesia. Para ele, o drama do proscrito se conjuga à situação existencial que se convergem num clima de exacerbado saudosismo. Tanto num como no outro, às imagens da pureza, da pacificação e da harmonia relativas à paisagem natal opõem-se as do clima gélido, do céu pesado das terras estrangeiras.

Compare nos versos seguintes dos dois poetas. Em Eugênio Tavares o poema "Exilado" traduz os contrastes entre a terra natal e espaço do exílio, este, descrito de forma bastante negativa: "Pensa no que há de mais sombrio e triste/ Soturnos céus - como tu nunca viste/ Do nosso sol parece a morta imagem/ Nas noites mais escuras, mais glaciais". Em Herculano, no poema 
"Tristezas do desterro", a terra onde o eu-lírico se encontra é vista também como um lugar inóspito: "Que o exílio condena ímpia sorte/ Sobre os plainos gelados do norte/ Luz do sol também desce do céu/ De um céu achatado e triste". Nos dois poetas, o exílio torna-se uma experiência vivida e a existência transforma-se em pesadelo e apenas a saudade pode aproximá-los dessa matriz perdida.

O pathos do exílio, resultante da cisão entre corpo e alma, desperta as reminiscências da pátria distante. A saudade, nesse caso, seria, na linha de uma tradição cultural portuguesa, a superação da expressão desse vazio provocado pela ausência dos emblemas nativos se dá pelo reencontro onírico e sacralizado do passado com o presente. Através dela, o diálogo com a terra e os seres ausentes pode ser restabelecido.

Para Eugênio Tavares, o exílio foi uma experiência marcante na sua vida e a obra desse período concatena diferentes elementos que expressam a sua sensibilidade romântica, e que traduz a sua concepção mundo. A maioria dessa produção tem como motivação a temática da saudade da terra natal e do lar, espaços sagrados para o subjetivismo romântico. O "eu" poemático do soneto "Minha casa" se dirige à sua terra natal como "minha pobre amada" e acrescenta que longe dessa "tudo me fere, tudo me molesta".

A saudade, substantivo característico do ideário romântico português, é uma constante no panorama literário desse período e aparece ligada ao cultivo do sentimento amoroso que os poetas dessa fase postulam em relação à sua terra natal e isso os leva a cultivar o saudosismo. Eugênio Tavares, na condição de exilado, explorou ao extremo essa temática. Nos poemas "Partindo" e "Saudade" estão repletos de recorrências ao apelo sentimental 
saudosista, tanto ao passado como à terra natal. Do primeiro poema temos na segunda estrofe: "Olhos na llha eu vi, amiga minha/ A pouco a pouco, num decrescimento/ Fugir o Lar, perder-se num momento/ A montanha em que o nosso amor se aninha". No segundo poema o autor expressa saudosamente os desenganos amorosos. Na primeira estrofe temos os seguintes versos: "O muito amor por teus olhos quebrados/ De sofrer esta adoração/ Por ti que me traspassa o coração/ Nas puas da saudade e dos cuidados”.

Os mentores do romantismo português, Almeida Garrett e Alexandre Herculano avivaram na temática do exílio o amor enternecido pela terra-mãe. 0 primeiro teve consciência do valor da saudade para definição da chamada "alma nacional", e por isso a invoca, mitificada no poema Camões: "Saudade, gosto amargo de infelizes".

A dor, o amor, a morte, a melancolia, a solidão, a noite, o sonho, o pessimismo, o saudosismo, a natureza, e a religiosidade são temáticas convencionais do romantismo que percorrem a produção poética de Eugênio Tavares. Cabe lembrar aqui que o conteúdo da poesia lírica é a maneira como a alma, com seus juízos subjetivos, alegrias e admirações, dores e sensações, toma consciência de si mesma. Na poesia lírica o que importa é a expressão da subjetividade bem como a manifestação da disposição da alma e dos sentimentos. Aliás, o vocábulo "lirismo" surgiu no interior do romantismo para designar o caráter acentuadamente individualista e emocional assumido pela poesia lírica a partir do século XIX.

Um dos grandes motivos da lírica romântica é a caracterização da dor e a poesia de Eugênio Tavares está carregada de elementos que falam do 
sofrimento da alma, das mágoas, das desesperanças, das angústias, das situações sem solução, da dor de viver a falência do amor.

No poema "A dor", o poeta resume todo o seu sofrimento diante da situação de abandono e perseguição do qual fora vítima. Para o eu-lírico somente o "sonho bom, vago e nebuloso é capaz de adormecer a dor". Temos aqui, a temática da evasão através do sonho, muito próprio do ethos da condição de insularidade vivida pelo caboverdiano e que irá compor o repertório temático da literatura caboverdiana.

\section{$\underline{\text { A dor }}$}

E se adormece a Dor, por um momento.

Num infantil cansaço lagrimoso, Um sonho bom e vago e nebuloso Envolve friamente o pensamento.

Apareces no plúmbeo firmamento;

O resplendor do teu olhar formoso

Relembra o sol rompendo um céu brumoso,

Pondo consolações no sofrimento.

És tu, Ventura, és tu! Bem reconheço

Tudo o que tanto amei e não mereço, Ó minha antiga e caprichosa amante!

Ventura, és tu! Mas nunca adormecesse

Essa que me consola e fortalece.

Ó minha Dor modesta, ó Dor constante!

Neste poema, o eu-lírico busca no sonho (evasão) o tempo da infância como conforto para os seus dissabores: "E se adormece a Dor, por um 
momento/ Num infantil cansaço lagrimoso/ Um sonho bom e vago e nebuloso/ Envolve friamente o pensamento". A reflexão sobre a experiência da dor é comum ao ser humano, mas há um aspecto da dor que é particular de quem a experimenta. A luta do poeta está em se aproximar o mais possível desse lado particular e único de tal experiência e imortalizar essa perspectiva impar da dor.

Ser escolhido pelo destino para sofrer é, afinal, uma tópica romântica que podemos encontrar em vários poetas do período. Como em João de Deus, que cultivou o gosto pelo sofrer ("que eu seja o único a sofrer, penar"17), a obra de Eugênio Tavares, na sua maioria, traz na sua essência a temática do sofrimento, do qual é bastante enfatizada, já que a mesma era fruto das suas próprias experiências.

Tendo em vista o diálogo entre a poesia de João de Deus com a de Eugênio Tavares comparemos os poemas "Dor", deste e "Ventura", daquele, principalmente no que diz respeito à saudade e o desencontro provocado pelo destino. Em "Ventura" temos: "Por ti, ventura ... que uma vez senti;/ Por ti que às vezes a meu peito aperto/ E... o peito aperto sem ti ver a ti!". Em "Dor" os seguintes versos traduzem um sentimento semelhante, temos: "És tu, ventura, és tu! Bem reconheço/ Tudo o que tanto amei e não mereço/ Ó minha antiga e caprichosa amante!".

O sofrimento por amor faz parte da tópica do ser destinado ao sofrimento. No poema "Sempre adorada", a suplica dirigida à amada é um lamento triste em que a dor da incompreensão entre os amantes ganha tons soturnos, como também entre as vicissitudes causadas pela ausência do ser amado, revelando-se um amor abnegado e submisso. 


\section{$\underline{\text { Sempre adorada }}$}

Desce comigo ao fundo deste horror

De ver, talvez, bem longe ainda o dia,

O dia de acordar para a alegria

Meu coração pela dor.

Desce comigo a este inferno, Amor;

À geleira da minha nostalgia;

Desce comigo, santa, e avalia

O que resta de tanto sonho em flor!

Entre os escombros da felicidade

Que, na ilusão gentil de curtos anos, Juntos erguemos numa esperança infinita

Tu verás, no regaço da saudade, Mal ferido do mal dos desenganos Minha alma doida a te adorar ainda!

"Sempre adorada" é um arrolamento de convites do "eu" poético para a amada. São convites muito comuns na proposta ultra-romântica: ir ao fundo do terror, descer ao inferno etc. O curto tempo de vida, gerado, via de regra, pela desengano diante dos sonhos de juventude, a exacerbação do sentimento e da adoração à amada também aparecem no poema: "Desce comigo, santa, e avalia/ O que resta de tanto sonho em flor!/ [...]/ Tu verás, no regaço da saudade,/ Mal ferido do mal dos desenganos/ Minha alma, doida, a te adorar ainda!"

\footnotetext{
${ }^{17}$ Verso do soneto "Ventura". In: Moisés 1968, p.282.
} 
O idealismo amoroso de cunho platonizante foi uma das prerrogativas do ultra-romantismo e diante da impossibilidade de concretizar a felicidade amorosa, o eu-lírico buscava na morte a evasão do sofrimento que o atormentava. Essa temática ganhou dimensões exacerbadas nas obras desse período e teve muito relevo na produção média dos aspirantes a poeta das colônias do ultramar.

\section{Meu bem}

Ai meu bem se eu não te amo Que eu seja um ente sem ventura Que as ondas do mar sanhudo Sejam a minha sepultura

Ai meu bem se eu não te amo Um passo não chegue a dar Que a própria Terra que eu piso Não me queira sepultar

Ainda depois da morte Lá debaixo do frio chão Acharás o teu nome escrito No meu coração

Se não crês no que te digo Aqui tens o meu juramento Acharás o teu nome escrito No meu eterno pensamento 
"Meu bem" mostra quão fundamental para o eu poético é o amor, a tal ponto que se ele não existir tudo fica "sem ventura" e é impossível avançar na caminhada. A força desse sentimento fará com que a amada encontre seu nome no coração e no pensamento do sujeito poético quando morto. O amor que transpassa a fronteira do falecimento é tema recorrente no Romantismo.

O desejo da morte foi um ideal estético e mesmo existencial de grande parte da geração romântica. Esse tema advém do mal estar que o indivíduo sente junto à sociedade. É o "mal du siècle", a doença que atinge os românticos, provoca a perda das forças e entedia a vida. Na verdade, essa sensação exprime o cansaço e a frustração resultante da impossibilidade de realizar-se plenamente.

Para o "eu" poemático da lírica de Eugênio Tavares a morte é vista de forma positiva, pois ela é uma das saídas para uma vida infeliz e sem expectativa. A morte para ele é uma "grande benfeitora" e a sua missão e dar "repouso à vida atribulada". No soneto "A morte" o "eu" a descreve de forma positiva e a mesma é personificada através da caricatura que sempre dominou

o imaginário popular. A imagem descrita é ao mesmo tempo funesta e redentora. De um lado, sua mão é "nívia de amor e ternura", do outro, "empunha a negra fouce tenebrosa". Estamos diante de uma visão antitética da morte.

\section{$\underline{\text { A morte }}$}

A morte é uma grande benfeitora Que tem, de Deus, essa missão sagrada

De dar repouso á vida atribulada, De dar liberdade redentora. 
Em seu regaço gélido, onde mora A paz do não sofrer tão almejada, Repousa a vaga essência desmaiada

Da dor da humanidade sofredora.

Sua mão regelada e piedosa,

Não é a inexorável mão escura

Que empunha a negra fouce tenebrosa.

É nívea mão de amor e de ternura

Que ampara e guarda - eterna mãe bondosa,

Perpetuamente, as almas sem ventura.

Esse soneto mostra qualidades positivas da morte. Essa "grande benfeitora" surge para aliviar a humanidade, alijando-a do tormento doloroso. Assim, o sujeito poético reivindica o estirpar da imagem do óbito como aquele que carrega medonhamente uma foice. A imagem verdadeira, segundo ele, da morte, é a da mãe que acolhe ternamente seu filho.

Através da morte há um regresso à autenticidade e, nela, o reencontro com o bem-estar, a harmonia completa. Para o romântico o poder da morte reside no poder que ela tem de afastá-lo, definitivamente, do seio de uma realidade que lhe é adversa.

Entre os românticos o estado de alma melancólico se desdobra em várias frentes temáticas como a solidão, o silêncio, a evasão, nesse caso, potencializada pelo sonho, e este se relaciona com a noite, lugar de onde vem à tona as emoções e anseios reprimidos. No poema "Realidade, sonho 
horrível", o eu-lírico se vê completamente impotente diante da situação de abandono e desventura.

Realidade, sonho horrível!

Fatigam-se as maiores desventuras, E dão momentos de tranqüilidade; Momentos em que a vítima se evade Do seu cárcere horrível de torturas.

Em que se enchem de estrelas as escuras

Longas noites da torva soledade;

E de olhos puros baixa a piedade, O bálsamo que estanca as amarguras

Mas nunca o sofrimento, de cansado, Me desse a vã miragem do impossível, Levantando-me o espírito prostrado.

Porque, sonhar aos beijos no intangível, E ter-se a crua realidade ao lado, É sonho mais pungente e mais horrível.

O sonho é a matéria-prima do suporte evasionista romântico, tanto o sono quanto a vigília. Nesse caso, o que se tem é algo parecido com um pesadelo, no entanto, o poema registra um momento de "respiro", no meio da tormenta: "Fatigam-se as maiores desventuras,/ E dão momentos de tranqüilidade". É a redenção para o sujeito poético: "Momentos em que a vítima se evade/ Do seu cárcere horrível de torturas".

Nessa vertente pessimista, o romântico se sente como um ser que perdeu todas as esperanças e que vê o mundo circundante como o espaço que 
o hostiliza, ao ignorar-lhe os anseios ou impedir-lhe a consecução dos desejos. No que diz respeito à solidão, recorde-se que essa decorre da inadequação do poeta romântico ao mundo real, onde não há lugar para o verdadeiro artista, pois a arte virou mercadoria, como bem demonstrou o trabalho dos críticos da Escola de Frankfurt. Então, ele encena o mergulho no seu mundo interior, já que o exterior não o compreende.

No soneto "Minha estrela" o poeta expressa o seu sentimento de solidão, resultado da experiência do exílio, lugar onde ele se encontra completamente desprotegido e longe dos amigos. Nesse poema, os traços de ligeira indignação, frente aos percalços do destino, contribuiu para a criação de uma atmosfera marcada por um forte acento existencial em que a desilusão e o pessimismo atuam como sentimentos recorrentes.

\section{A minha estrela}

Trazem meus olhos tão desconsolados

Saudades de te ver um riso amigo,

Que já os não levanto, resignados.

Num implorar humilde de mendigo.

E se uma vez os ergo, é que persigo

Outra esperança em teus olhos velados.

Já não aspiro à luz; busco abrigo, Procuro a sombra, a mãe dos desgraçados.

Destruída a ilusão, senti a vida Fugir do coração desenganado; Vi a esperança última perdida, 
Como no vento a folha desprendida;

E o homem, na corrente arrebatado, Vogou qual ninho de ave desmanchado.

A noção de busca fica evidente nesse poema, principalmente pelos verbos usados: "persigo", "aspiro", "busco", "procuro". É possível que o alvo dessa busca seja a morte, metaforizada como "a mãe dos desgraçados". O tema da morte em vida parece estar presente nestes versos: "Destruída a ilusão, senti a vida/ Fugir do coração enganado/ Vi a última esperança perdida".

Diante da situação de conflito do "eu" com o mundo real resta para o romântico o sonho como única possibilidade de realização individual. Sendo assim, o sonho é o estado ideal que o romântico possa comunicar com a realidade profunda do universo, insusceptível de ser apreendida pelos sentidos e pelo intelecto. $\mathrm{Na}$ verdade, o sonho se constitui no elemento de extrema importância na concepção romântica da criação poética. O sonho em Eugênio Tavares tem a ver com a utopia social, ou seja, com a possibilidade de um devir.

Na criação poética de Eugênio Tavares o sonho é um recurso do estado de alma o eu-lírico diante da inevitável situação de desamparo e impotência em relação aos anseios de justiça e liberdade defendidos pelo poeta. Nos poemas dessa fase marcada pelo pessimismo aparecem inúmeros versos de diferentes poemas em que o sonho como evasão da realidade se faz presente.

\section{$\underline{\text { O sonho }}$}

Quando um dia eu voltar desta viagem, Hei de trazer-te o Sonho cuja ausência 
Te tem posto pezares na existência, $\mathrm{Na}$ tua vida branda como aragem.

Se eu lá ficar, porém, nessa miragem

Que acolhe os tristes, cheia de clemência

Há de voltar a ti a vaga essência

Do eterno amor, em pálida romagem.

Minha alma há de voltar a contemplar-te

E há de ouvi-la num choro doloroso

Rogar a Deus de ti jamais a aparte

E quando soar-te a hora da partida

Como um par de andorinhas, amoroso

Iremos juntos, desta à outra vida.

Apesar de todas as circunstâncias que impediram a realização dos seus ideais, a esperança continua viva através do sonho, e quando o "eu" voltar dessa viagem, ou seja, do exílio, seus objetivos continuaram presentes, mesmo que esses tenham-Ihe causado tantos "pesares".

Em relação à recorrência romântica, a temática da religiosidade aparece intimamente ligada à tradição cultural portuguesa e perpassa toda a sua literatura, ganhando bastante destaque na poesia dessa fase literária. A obra de Eugênio Tavares dialoga com essas referências através de uma imagética de cunho cristão em que as simbologias e as figuras se destacam como lugares comuns do ideário ultra-romântico. No entanto, em decorrência do seu amadurecimento intelectual e constantes desilusões, já é possível verificar uma certa descrença e um acento irônico em relação às suas conviç̧ões religiosas como podemos perceber no poema "Deus". Aqui, Deus é visto como um ser 
complemente alheio aos problemas dos injustiçados e é chamado a assumir o seu papel de supremo defensor daqueles que sofrem.

\section{Deus}

Dormes, Sombra enigmática? Repousas, Anojado de ver o fero Mal

Cravar, impunemente, o seu punhal

No coração do homem? E não ousas

Desviar os teus olhos para as cousas

Que fermentam no fundo desse urzal

Da alma humana? Será, Deus eternal,

Esse teu sono o último, de lousas?

Sentes jorrar o sangue da inocência,

E vês correr as lágrimas dos tristes?

Não ouves o estertor da consciência

Estrangulada? Indiferente assistes

À acção feroz do crime? Omnipotência!

Esse teu sono é morte! Não existes!

O sujeito poético lança seu discurso pleno de ira, questionando o sono divino diante dos tormentos do mundo. Inclusive, questionamento é o que não falta nesse poema em que é usado o ponto de interrogação por seis vezes. $O$ ponto de exclamação aparece três vezes. Assim, o "eu" poemático segue em seu discurso contundente, crítico e pasmado, e ao final conclui: o sono de Deus é, na verdade, a sua morte, já que ele não existe. 
Deus teve um lugar de relevo na poesia romântica portuguesa, sobretudo em Herculano, Soares de Passos e João de Lemos. Em "Cruz mutilada", por exemplo, Herculano faz uma reflexão bastante explícita sobre a morte, sobre Deus e sobre o contraste entre a transitoriedade humana e o infinito que é a transcendência religiosa.

Várias são as referências ao cristianismo no conjunto de sua obra. Nos versos seguintes podemos constatar essa tendência em: "E implora a Deus a paz final da morte", do soneto "Dia de chuva". Do poema "O sonho" temos: "Rogar a Deus de ti jamais a aparte". Em "Daria a vida" aparece os seguintes versos: "Quem isto me afirmasse, oh! Deus, sei lá!/ Se eu lhe daria até a própria vida". A última estrofe do soneto "Saudade" os substantivos "cruz", "almas" e "luz" nos remetem ao imaginário cristão, já que esses elementos fazem parte do repertório simbólico da fé popular: "porque amarrados numa cruz/ Embora separados, nossas almas/ Formam uma só vida, uma só luz".

A poesia em língua portuguesa de Eugênio Tavares, apesar de apresentar uma faceta convencional, segundo os parâmetros estéticos do ultraromantismo, inova ao recontextualizar aquela convenção.

Sua obra reflete as suas experiências pessoais, em que poesia e autobiografia se confundem. A temática do amor, do exílio, da morte e do sonho, como aspirações libertárias e sociais predominam no repertório temático de suas criações. Por outro lado, já é possível vislumbrar temas que num futuro próximo seriam muito caros aos claridosos: evasão, insularidade, mar, seca e um certo nativismo de cunho político etc., ainda que não da mesma perspectiva que aqueles. 
Seguindo essa perspectiva podemos depreender que, apesar do apelo romântico que caracteriza sua obra, o autor não perdeu de vista a sua individualidade, relevando assim, certos aspectos originais, principalmente em relação à temática radicada nas particularidades enraizadas na cultura local.

Sobre a temática da evasão, ou seja, o conflito entre a necessidade de partir e o desejo de permanecer, temática emblemática da literatura caboverdiana, na sua obra do exílio é bastante recorrente. Nessa, o autor, embasado pelo imaginário romântico, buscou no sonho, o desejo de evadir-se do espaço estrangeiro para o aconchego de sua terra natal, do estado de opressão para a liberdade, como podemos verificar nos versos dos poemas "A valsa" "Não me pertence". Deste temos: "Talvez eu desse tudo: a imensidade/ do amor; o sonho taciturno e mudo;/ Toda a luz da razão; a flor do estudo;/ O fruto da lição e da verdade". [...] "Daria esta alma louca de saudade/ Daria o meu futuro carrancudo/ A minha carne à dor, daria tudo/ Tudo, menos a minha liberdade". Daquele aparece os seguintes versos: "Rompeu a valsa nos bordões tão graves/ Da guitarra. Sonhando vagamente,/ Revoa o meu espírito doente,/ Num ângelus de lágrimas suaves." [...] "Eu vou sonhando: O meu primeiro amor/ Abeira de mim./ Falo-lhe, flor!/ É isto sonho, ou é realidade?".

Segundo Mariano (1991, p.103), "em Eugênio Tavares a partida surge como uma imposição, não como desejo". E completa afirmando que: "o conteúdo dinâmico do "querer ficar", o seu lastro sentimental, surge simbolizado na "cetcheu", no amor, já que este, é uma forma de convívio, de diálogo e que aparece inseparável da partida".

O mar, elemento ambíguo, águas que isolam o homem no seu espaço cotidiano e ao mesmo tempo é o elemento que possibilita a abertura para o 
desconhecido, para o sonho e a imaginação aparece na poesia de Eugênio Tavares no poema "Canção do mar". O mar, como expressão subjetiva da poesia desse poeta, traduz a convivência do ser caboverdiano com o mar.

Neste poema estamos diante da personificação do mar, do qual o "eu" evoca como único ser capaz de ouvir suas lamentações e atender seus pedidos. Para o caboverdiano, o mar está intimamente ligado a sua existência. Nos seguintes versos podemos perceber como o poeta se relaciona com 0 mar. Às vezes com intimidade, outras com reverência. Temos; Oh mar eterno sem fundo, sem fim/ Oh mar de túbidas vagas/ [...] "Suspende a zanga um momento/ Escuta/ [...] "Dá-me notícias do meu amor/ Que um dia os ventos do céu/ Oh dor!/ Nos seus braços furiosos/ Levaram". A evocação ao mar é uma atitude muito peculiar neste poema, aqui o mar é visto como um ser supremo a quem o "eu" recorre em seu momento de aflição. Esse sentimento de aprisionamento e contato com o mar é uma constante enfrentada pelos ilhéus, o que definimos como insulamento.

Segundo Elsa Rodrigues dos Santos ${ }^{18}$, a insaluridade é uma situação muito própria do ser caboverdiano dado às circunstâncias da sua composição geográfica, fato que condiciona o seu estado de espírito. Para a autora, "o sentimento de solidão, de nostalgia que o ilhéu experimenta face ao isolamento e aos limites da fronteira líquida que o separa do resto do mundo, criando-Ihe um estado de angústia e de ansiedade que o levou a sonhar com outros horizontes além do mar".

Assim como o mar é uma presença constante na vida do caboverdiano, a seca também, por mais adversa que seja, tem condicionado a vida desse povo. A literatura, a partir dos Claridosos elegeram-na como temática emblemática da sua constituição identitária, no entanto, já vislumbramos uma certa referência a 
essa temática em vários poemas de Eugênio Tavares, como em "Os miseráveis" e em "Triste regresso", este, também explora o ethos da partida e seu conseqüente retorno.

Em "Os miseráveis" o poeta explora a temática social bem ao gosto romântico que caracterizaram boa parte da produção desse período e que no Brasil teve em Castro Alves principal expoente. O poeta descreve uma situação muito comum em Cabo Verde, a fome, causadas pelas freqüentes estiagens, que tomava dimensões catastróficas com a morte de milhares de caboverdianos. Aqui, o eu-lírico imbuído de compaixão expressa toda sua solidariedade a uma mãe esfarrapada. Citamos alguns trechos desse poema, temos:"Trazei, ó pobres mães esfarrapadas/ Ó mães de emagrecidos seios/ Trazei à minha dor, aos meus anseios/ As vossas falas pálidas, veladas.” [...] "O mal que nos esmaga e nos dessora/ Se a um só despedaça sem demora,/ A muitos é mais leve de arrasar".

O poema "Triste regresso", escrito num de seus retornos clandestinos à ilha natal, o autor descreve a sua chegada numa manhã em que a névoa cobre o arquipélago. Aqui, a visão do poeta, pautado pelo subjetivismo, é bastante peculiar, dotando a paisagem de um certo caráter místico e difuso. Em relação à questão da seca, o poeta mostra o quanto o sol é inclemente com a vegetação do arquipélago através do dano deste às arvores. Personificado como um rei homicida, as árvores, vítimas de sua tirania e diante da falta de chuvas, erguem os seus braços retorcidos clamando por piedade. "Da c'roa do platô à fímbria da leveza/ As árvores sem vida estorcem-se de sede/ E o sol bem como um rei fanático, homicida, - fustiga-as a matar/ E ri-se ao incendiar/

\footnotetext{
18 Trecho da tese da autora “As máscaras poéticas de Jorge Barbosa, p.89.
} 
Os ramos - como mãos erguidas de quem reza/ $\mathrm{E}$ as folhas - como mãos abertas de quem pede/ Das árvores sem vida." Comparação bastante ilustrativa dos efeitos da seca na paisagem e na vida dos ilhéus.

$\mathrm{Na}$ trilha da constituição da identidade e do sentido de caboverdianidade a composição "Crioulas", poema da fase madura do autor, resgata a condição mestiça da cultura local, temática que irá repercutir nas produções futuras e que é sinônimo da alma caboverdiana.

\section{$\underline{\text { Crioulas }}$}

A virgem Maria

Pura mãe de Deus

Seria crioula?

Sim; nos sonhos

Meus,

Contemplo-a

Morena,

Filha de plebeus,

Morena crioula

Rainha dos céus...

Nos seus tristes

Olhos

Boiados de amor,

Há consolações,

Para toda dor

A doce crioula

Pequenina flor

É como a violeta no aroma, na cor. 
Neste poema (Crioulas) o autor presta uma homenagem à mulher crioula caboverdiana comparando-a a nossa Senhora. Estilisticamente bem elaborado, o autor conjuga o processo de mestiçagem cultural, que é o elemento central da cultura caboverdiana, a partir dos esquemas simbólicos de cunho cristão. A relação entre a virgem e a crioula é feita a partir dos atributos comuns a ambas, no entanto, a virgem crioula parece mais próxima dos anseios do poeta. Em "Crioulas", a mulher caboverdiana é objeto de admiração e exaltação. Destituída de sensualidade e idealizada, a figura feminina ganha contornos divinos e como criatura inacessível freqüenta os sonhos do poeta.

Quanto a sua poesia de cunho político, lembramos que toda a produção do período em que o poeta se sentiu perseguido pelo poder colonial apresenta de forma bastante explícitas elementos que caracterizam o seu estado de alma, em que as injustiças sofridas seria uma resposta ao seu posicionamento ideológico contra o sistema político colonial. O poema "Esperança" ratifica essa situação através dos seguintes versos: "Erga-se o Mal que os corações aterra/ Caia, como um sudário, a grande calma/ Do seu olhar voltado sobre a terra/ [...] "Morra, enfim, quanta Luz a Idéia alcança/ Que ainda no seio férvido de uma alma/ Há de sorrir a estrela da Esperança." Atentemos para os vocábulos escritos em maiúsculo "Mal, Luz, Idéia e Esperança". Numa leitura política desse poema podemos relacionar "Mal" à atitude irracional dos seus inimigos do poder contra os ideais defendidos pelo poeta e diante da situação de injustiça só restaria para ele a Esperança, como única saída.

$\mathrm{Na}$ trajetória de sua criação poética do período do exílio, discutida anteriormente, foi fundamental para o amadurecimento de suas convicções políticas. Os poemas escritos após o seu retorno definitivo à sua terra natal 
expressam os seus ideais políticos e apresentam os seus anseios libertários de forma bastante contundente. O poema "Hinos" é emblemático desse contexto em que confluem diferentes orientações ideológicas, embora o desejo de independência seja sua posição predominante.

\section{$\underline{\text { Hinos }}$}

Revolução ou morte! Eis o nosso dever A paz é, já, um crime; e morte infame, a vida! E se havemos de, - irmãos! ... um dia apodrecer

No ventre desta terra infausta, tam querida;

Se a Pátria santa ao mal temos que ver rendida;

Se a aurora do combate um dia há de romper; Se a lágrima, e o suor, e o sangue hão de correr, Avermelhando o mar e a terra envilecida;

E se hão de, num futuro incerto, derramá-los, Filhos do nosso amor ás mãos dos mercenários, Pátria e filhos - irmãos! ... tentemos nós salvá-los!

Morte ou Revolução! Que, não há cobardia Que iguale a de legar a filhos os calvários De nomes com brazões de lodo e vilania!

Este poema (Hinos) é um grito inflamado do poeta contra a condição colonial. O poeta conclama os seus concidadãos para lutarem pela liberdade de Cabo Verde. Há neste escrito um furor nacionalista que dialoga com os ideais de liberdade proposto pelo movimento pan-africanista e que tem sua 
base nos ditames da revolução francesa e converge como unidade ao sonho de independência das demais colônias de África.

As convenções literárias que dominaram as décadas finais do século XIX e inicio do século $X X$ nas colônias portuguesa da África tiveram como paradigma os autores portugueses românticos de diferentes gerações. Esses modelos te chegaram com algum atraso no espaço colonial, mas sua presença foi fundamental para o surgimento de um meio cultural e literário naquelas paragens. No entanto, apesar desses condicionamentos, muitos poetas não perderam de vista a sua individualidade e souberam adequar elementos particulares da sua experiência a essas convenções, como é o caso da poesia em língua portuguesa de Eugênio Tavares. 


\section{Conclusão}

As manifestações literárias em Cabo Verde se iniciam a partir da instauração da imprensa em 1842 e cobrem um período bastante extenso da história caboverdiana. Essa fase inicial foi marcada por uma intensa produção literária, embora esses textos não representassem o verdadeiro sentido da identidade cultural local.

As convenções literárias que predominaram a partir dos meados do século XIX no espaço colonial caboverdiano fazem parte do ideário cultural advindos da tradição literária portuguesa através do processo de assimilação propagado pela formação escolar e pela circulação literária difundida pelos periódicos e revistas desse período.

Situada em um espaço fragmentado, onde a dificuldade de locomoção entre as ilhas era um forte empecilho para o contato direto entre as diferentes comunidades, a imprensa tinha, não só a função informativa, como também um papel social muito peculiar, pois era o principal meio de intercâmbio entre os habitantes do arquipélago.

Sendo assim, as condições geográficas e o meio social caboverdiano favoreceram tanto o desenvolvimento da imprensa em Cabo Verde, como a circulação de diferentes manifestações literárias, principalmente no âmbito da poesia lírica, já que essa atingia um público médio bastante expressivo, o que de certa forma propiciou o surgimento de um ambiente cultural muito peculiar em relação às outras colônias da África. 
Denominada de literatura de "subsistência", a maioria dos autores desse período, ou seja, os colaboradores dos periódicos, não se preocupavam, de certa forma, com questões referentes à originalidade e ao apuro estético, já que o grosso dessas produções tinha um caráter "utilitarista", servindo apenas como meio de interação entre os próprios escritores e alguns leitores nas datas comemorativas, festas e dedicatórias.

A poesia em língua portuguesa de Eugênio Tavares foi escrita entre a duas últimas décadas do século $\mathrm{XIX}$ e primeiras do século $\mathrm{XX}$ e teve como meio de divulgação a imprensa da época, através de suas freqüentes colaborações nos espaços literários dessas publicações. Sua obra, apesar do discutível valor estético, reflete bem as convenções literárias vigentes no espaço colonial caboverdiano, onde o romantismo, principalmente 0 da segunda geração portuguesa, exerceu uma forte influência nas produções poéticas de todo o macro sistema português.

Pautada pelo convencionalismo dominante, sua poesia se caracteriza por um forte apelo saudosista e sentimental, bem ao gosto médio do público receptor dessa época. Nesse pequeno corpus podemos perceber a relação demasiada intensa entre os acontecimentos que marcaram a sua vida e a temática de sua obra.

Embora a maioria das produções desse período tenha um caráter apenas utilitário, a obra de Eugênio Tavares já apresenta uma certa preocupação de originalidade estética e formal, o que se conclui que o autor tinha não só o conhecimento da literária portuguesa que Ihe era contemporânea, mas também o pleno domínio das formas mais comuns usadas pelos autores dos diferentes períodos dessa literatura. 
O soneto foi uma das formas preferida pelo poeta. Aparece na maioria da sua produção, principalmente na do período do exílio, mas podemos encontrar a presença tanto das redondilhas quanto de quadras em sua obra. Quanto à temática, podemos perceber que essa segue o padrão comum bem ao gosto do ultra-romantismo. A dor, a morte, a desilusão amorosa, a incompatibilidade do eu-lírico com a realidade e o anseio individualista formam o conjunto temático de sua poesia.

O seu percurso, enquanto intelectual e poeta, é bastante singular, dadas as condições histórico-sociais do meio colonial, principalmente o que cobre o período mais produtivo de sua trajetória política e literária.

A sua adesão aos ideais republicanos e a sua militância contra a política colonial portuguesa tiveram bastante repercussão entre a elite intelectual e os setores da burguesia colonialista da época, o que the acarretou sérios problemas com a justiça portuguesa, resultando na sua fuga para o exílio.

O exílio foi para Eugênio Tavares uma fase muito peculiar de sua vida, apesar de todo o sofrimento expresso pela poesia desse período, entendemos que esse momento foi bastante proveitoso, pois the propiciou o contato com novas idéias e correntes políticas em voga no ocidente e que só veio ratificar as suas convicções políticas.

O foco das suas colaborações jornalísticas que até então eram pautadas apenas pela crítica em relação à política colonial ganharam um novo viés a partir da sua estada no exílio. Nesses textos, o autor passa não só a denunciar os desmandos da administração, como também a defender a independência de Cabo Verde, o que o qualifica como um dos pioneiros do nativismo caboverdiano. 
Entretanto, em relação às convenções literárias que predominaram neste contexto e a sua produção em língua portuguesa, podemos inferir a antecipação de temáticas que repercutiram na poesia caboverdiana a partir do movimento da Claridade como "o mar, a seca, a insularidade, a evasão e o nativismo", embora esses temas ainda aparecem pautados pelo ideário romântico.

Sendo assim, a obra poética e jornalística de Eugênio Tavares é fundamental para a compreensão da história político-cultural caboverdiana desse período. Sem contar que, tanto a sua poética, como a sua intervenção jornalística reflete as questões mais prementes que marcaram o homem e a história do período colonial em Cabo Verde. 


\section{Referências Bibliográficas}

\section{SOBRE A BIOGRAFIA DE EUGÊNIO TAVARES}

www.eugeniotavares.org

\section{BIBLIOGRAFIA GERAL}

BARROS, Carlota de. Barros, Viriato. O amor em Eugênio Tavares. Extrato da conferência proferida na Hemeroteca Municipal de Lisboa. In: www.eugeniotavares.org/docs/pt

BLOOM, Harold. A angústia da influência: uma teoria da poesia. Trad. Arthur Nestrovski. Rio de Janeiro: Imago Ed., 1991.

BOSI, Alfredo. O ser e o tempo da poesia. São Paulo: Cultrix, Ed. da USP, 1997.

CANDIDO, Antonio. Literatura e sociedade: estudos de teoria e história literária. 7.ed. São Paulo: Ed. Nacional, 1985.

. O estudo analítico do poema. São Paulo, Associação Editorial Humanitas, $4^{\mathrm{a}}$ ed. 2004.

. Formação da literatura brasileira. 2ำ volume. Belo Horizonte, Ed. Itatiaia Limitada, 8ª ed. 1997.

O romantismo no Brasil. São Paulo, Humanitas, 2004

CANIATO, Benilde Justo. Percursos pela África e por Macau. Cotia, Sp: Ateliê editorial, 2005

CARA, Salete de Almeida. A poesia lírica. 3aㅡ ed. S.Paulo. Editora Ática, 31989. 
CARDOSO, Pedro Monteiro. Folclore Caboverdiano. Lisboa, Solidariedade, 1983.

CARREIRA, António. Cabo Verde (Aspectos sociais, secas e fomes do século XX). 2aㅡ ed. Lisboa, Ulmeiro, 1984.

CARVALHAL, Tânia Franco. Literatura Comparada . São Paulo, Ática , 2003

CITELLI, Adilson. Romantismo. São Paulo, Ed. Ática, 1986.

CLARIDADE: REVISTA DE ARTE E LETRA. Organização, coordenação e direção de Manuel Ferreira. Lisboa, Ed. Alac, 2ª ed. 1986.

DIALOGISMO, Polifonia, Intertextualidade: Em torno de Bakhtin. (org.) Diana Luz pessoa de Barros e José Luiz Forin, São Paulo, Edusp.

DUARTE, Dulce Almada. Ruptura e afirmação na literatura cabo-verdiana. A poética da Claridade. In: Nacionalismo e regionalismo nas literaturas lusófonas. Fernando Cristóvão, Maria de Lourdes Ferraz e Alberto Carvalho (org.) Lisboa, Edições Cosmos, 1997

EUGÊNIO TAVARES PELOS JORNAIS... Recolha, Organização e Prefácio de Félix Monteiro. Praia, Documentos, Instituto Caboverdiano do Livro e do Disco, 1997.

FERREIRA, Manuel. O discurso no percurso africano I. Lisboa, Plátano Editora, 1989.

---------. A aventura Crioula. 3ae ed. Lisboa, Plátano Editora, 1985.

----------. Literaturas Africanas de expressão portuguesa. S.Paulo, Ática, 1987 No reino de caliban I. Lisboa, Plátano editora. 
FIORIN, José Luiz. Bakthin e a concepção dialógica da linguagem. In: Margens da Cultura/ Mestiçagem, Hibridismo \& outras misturas. Benjamin Abdala Junior (org.) São Paulo, Boitempo Editorial, 2000.

FORTES, Corsino. Eugênio Tavares: Um construtor do humanismo caboverdiano. Comunicação apresentada no colóquio internacional Humanismo Latino na Cultura Portuguesa em 2002 na FLUP/Porto.In: www.humanismolatino.online.pt

FOUCAULT, Michel. O que é um autor? Trad. Antonio Fernandes Cascais. Portugal, Vegas, 2002.

GARMES, Hélder. A convenção formadora: uma contribuição para a história do periodismo literário nas colônias portuguesas. Tese de doutoramento - S.Paulo, 1999

O pioneirismo político e literário da Revista de Cabo Verde.

Scripta v.10, n.19. Lélia Parreira Duarte (org.) Belo Horizonte, 2006. Identidade mestiça de Goa a Cabo Verde. In: Literaturas e movimento/ Hibridismo cultural e exercício crítico. Rita Chaves e Tânia Macedo (org.), Coleção Via Atlântica, ํ5, São Paulo, 2003.

GOLDSTEIN, Norma. Versos, Sons, Ritmos. São Paulo, Ática,13å ed. 2000.

GRUZINSKI, Serge. O pensamento mestiço. São Paulo, Cia da letras, 2001.

GUILLÉN, Cláudio. A estética do estudo de influências em literatura Comparada. In: Literatura Comparada/textos Fundadores - Org. Eduardo F. Coutinho e Tânia Franco Carvalhal.Rio de Janeiro Rocco, 1994

GUIMARÃES, José António Nobre. O nativismo em Eugênio Tavares. Comunicação apresentada na conferência sobre Eugênio Tavares 
na Hemeroteca de Lisboa em 29 de março de 2005. In: www. Eugeniotavares.org/docs/pt

HAMILTON, Russel G. As origens de uma sociedade crioula.In: Literatura africana/Literatura necessária II. Lisboa. Edições 70, 1984.

HERNANDEZ, Leila Maria Gonçalves Leite. Os filhos da terra do sol: A formação do Estado - Nação em Cabo Verde. São Paulo - Sumus, 2002.

As rotas para a independência e o fim do "ultracolonialismo". In:

A África na sala de aula: Visita à História Contemporânea. São Paulo, Selo Negro, 2005.

JENNY, Laurent. A estratégia da forma In: Poétique: revista de teoria e análise literárias - Coimbra. Livraria Almedina, 1079.

JUNIOR, Benjamin Abdala. Cabo Verde: o contato de culturas In: De vôos e Ilhas: Literatura e Comunitarismos - Cotia, SP.

Ateliê Editorial, 2003

LARANJEIRA, Pires. De letra em riste: Identidade, autonomia e outras questões nas literaturas de Angola, Cabo Verde, Moçambique e S. Tomé e Príncipe.Porto, Edições Afrontamento, 1992.

------------. Literaturas Africanas de Expressão Portuguesa. Com a colaboração de Inocência Mata e Elsa Rodrigues dos Santos. Lisboa, Universidade Aberta, 1995.

LOPES, Oscar. Trinta anos de poesia otocentista (1860 - 1890)/Panorâmica. In: Álbum de Família: ensaios sobre autores portugueses do século XIX. Lisboa, Editorial Caminho, 1894. 
LUCAS, Fábio. Fontes literárias portuguesas. Campinas, Pontes/Secretaria de Estado da Cultura, 1991.

MACHADO, Álvaro Manuel. O romantismo na poesia portuguesa ( de Garret a Antero). Lisboa, Biblioteca breve no 14, Instituto de cultura e língua portuguesa, 1986.

MARGARIDO, Alfredo. Estudos sobre literaturas das nações de língua portuguesa. Lisboa, A regra do jogo, 1980.

MARIANO, Gabriel. Cultura Caboverdiana. Lisboa, Ed. Vegas, 1991.

MOISÉS, Carlos Felipe. Poesia não é difícil. Porto Alegre, Ed. Artes e Ofícios, 1996.

Poesia \& Utopia - Sobre a função social da poesia e do poeta. São Paulo, Escrituras Editora, 2007.

MOISÉS, Massaud. Literatura: mundo e forma. São Paulo, Cultrix/Ed. Da Universidade de S.Paulo. 1982.

A literatura portuguesa através dos textos. São Paulo, Editora Cultrix, 1968.

MONTEIRO, Félix. Páginas esquecidas de Eugênio Tavares. IN Raízes no 17/20 - ano 5, Cabo Verde, 1981.

NOVA HISTÓRIA DA EXPANSÃO PORTUGUESA. Direção de Joel Serrão e A. H. Oliveira Marques. Volume XI, O Império Africano 1890-1930. A. H. Oliveira Marques (coord.). Lisboa, Editorial Estampa, 2001.

PAULINHO, Graça; WALTY, Ivete;CURY, Zilda. Intertextualidade: teoria e prática. Belo Horizonte, Editora Lê, 1998. 
PORTUGAL, Francisco Salinas. Entre Próspero e Caliban: Literaturas africanas de Língua Portuguesa. Santiago de Compostela, Edicións Laiovento, 1999.

ROMANO, Luís. Cabo Verde - Renascença de uma civilização no atlântico médio.2 $2^{a} e d$. Lisboa, Edição da Revista Ocidente, 1970.

SAID, Edward. Reflexões sobre o exílio. In: Reflexões sobre o exílio e outros ensaios. Trad. Pedro Maria Soares. São Paulo, Cia da Letras, 2001.

SANTILLI, Maria Aparecida. Estórias africanas; história \& antologia. São Paulo, Ática, 1985.

SARAIVA, Antonio José e Lopes, Oscar. História da literatura portuguesa. Porto, Porto Editora, $7^{\mathrm{a}}$ ed, 1955

SIMÕES, João Gaspar. Itinerário histórico da poesia portuguesa 1 de 1189 a 1964. Lisboa - Arcádia.

TAVARES, Eugênio. Mornas: Cantigas crioulas. Luanda, Edição da Liga dos Amigos de Cabo Verde, Luanda, 1969.

TRIGO, Salvato. A alteridade das literaturas africanas em língua portuguesa. In: Ensaios de Literatura Comparada/Afro-luso-brasileira. Lisboa, Vega, 1985. 


\title{
Anexo
}

\section{Poemas esquecidos de Eugênio Tavares}

\author{
À badinha \\ Um dia cahira em teu níveo seio \\ Desmaiado botão, \\ Que d'uma linda roseira arrancara \\ Violento tufão. \\ As tuas carícias deram-lhe vida \\ E o anhelito teu \\ Foi o bálsamo que deu força, alento \\ Ao débil peito seu! \\ E a carmínea bonina transformou-se \\ Rapidamente em flor, \\ Que se esforça por derramar a jorros \\ Reconhecido odor! \\ O immaculado Anjo da caridade, \\ Que do Olympo desceu, \\ És tu! E a flor, que, meiga e carinhosa, \\ Emballaste, sou eu!
}

\section{Meu bem}

Ai meu bem se eu não te amo

Que eu seja um ente sem ventura

Que as ondas do mar sanhudo

Sejam a minha sepultura 
Ai meu bem se eu não te amo Um passo não chegue a dar Que a própria Terra que eu piso Não me queira sepultar Ainda depois da morte Lá debaixo do frio chão Acharás o teu nome escrito No meu coração

Se não crês no que te digo Aqui tens o meu juramento Acharás o teu nome escrito No meu eterno pensamento

\section{Cancões aladas}

Canções aladas

Notas saudosas

Em lágrimas orvalhadas

Ide, voai pressurosas

Não há melhor remédio

Que o doce bem de cantar

Quando a saudade e o tédio

Nos obrigam a chorar

Buscai a estância

Do nosso amor

Vencei a imensa distância

Que vai das águas à flor 
Ide cantar

As bem-amadas

Nosso indizível penar

Sobre as ondas inclinadas

Que o pranto inunda

Nossa existência

$\mathrm{Na}$ dor imensa e profunda

Na dor enorme da ausência

Que a mágoa é tanta

Tão de matar

Que a gente até quando canta

Canta e ri para enganar

Meiga saudade

Tu és tão forte

Que vences minha vontade

De fugir para a morte

Lanças na dor

As almas tristes

Mas a vida e o amor

Existem porque existes

Qual andorinha

Por sobre os mares

Abre vôo sozinha

Portadora de cantares 
És companheira

Dos embarcados

Saudade voa ligeira

Leva a voz dos exilados

Canta a sofrer

Canta a agonia

Dos que partem sem saber

Se voltarão algum dia

Que um sentimento

Que amansa o mar

Faz calar a voz do vento

Põe as ondas a chorar

Um sonho vão

Nos arrebata

Canta o orgulho, a ilusão

Canta a dúvida que mata

Oh canta o azul

E o largo mar

A quente aragem do sul

Da esposa, o suave olhar

Ai canta a morte

Em que se esquece

Canta a vida inteira e forte

Do amor que nunca arrefece. 


\section{Camponesa formosa}

Oh camponesa formosa

De olhos gentis de matar Vem clarear a tristeza

Com a luz do teu olhar

Tu que descalça e risonha,

Corres por montes e vales

Deixa que eu siga os teus passos

Deixa que eu fuja aos meus males

Mostra-me o trilho florido

Que ao teu afecto conduz,

Dá-me o teu braço amável

Sou um ceguinho sem luz

Oh camponesa formosa

De olhos gentis de matar

Dá-me o teu braço e partamos

Vamos cantar e sonhar

Oh camponesa formosa

De olhos gentis de matar

Vem clarear-me a tristeza

Com a luz do teu olhar

Leva-me assim pelas mãos

Lá pelos remansos da serra

Tira-me tu da cidade

Que me entristece e aterra 
Hei de adorar-te e servir-te

Como Jacob a Raquel

Hei de morrer a teus pés

Como o teu cão mais fiel.

\section{Canção do mar}

Oh mar eterno sem fundo

Sem fim

Oh mar de túrbidas vagas

Oh mar!

De ti e das bocas do mundo

a mim

Só me vem dores e pragas

Oh mar!

Que mal te fiz oh mar, oh mar

Que ao ver-me pões-te a arfar, a arfar

Quebrando as ondas tuas

De encontro às rochas nuas

Suspende a zanga um momento

Escuta

A voz do meu sofrimento

Na luta

Que o amor acende em meu peito

Desfeito

De tanto amar e penar

Oh mar! 
Que até parece, oh mar, oh mar!

Um coração a arfar, a arfar

Em ondas pela fráguas

Quebrando em mágoas

Dá-me notícias do meu amor,

Amor

Que um dia os ventos do céu

Oh dor!

Levaram

E ao meu sorriso, invejosos,

Roubaram

Não mais voltou ao lar, ao lar

Não mais o vi oh mar, oh mar

Mar fria sepultura

Desta minha alma escura

Roubaste-me a luz querida

Do amor,

E me deixaste sem vida

No horror

Oh alma da tempestade

Amansa

Não me leves a saudade

E a esperança

Que esta saudade, é quem, é quem

Me ampara tão fiel, fiel

É como a doce mãe

Suavíssima e cruel

Mas mágoas desta aflição 


\author{
Que agita \\ Meu infeliz coração, \\ Bendita, \\ Bendita seja a esperança \\ Que ainda \\ Lá me promete a bonança \\ Tão linda!
}

\begin{abstract}
A valsa
Rompeu a valsa nos bordões tão graves

Da guitarra, sonhando vagamente,

Revoa o meu espírito doente, Num ângelus de lágrimas suaves.

Crescendo no horizonte, como naves

Que regressam, num pálido poente,

Os dias que morreram tristemente,

Voltam em bandos, como bandos de aves

Plúmbeas recordações duma outra idade

Chegam nas asas roxas da saudade, E acordam a minha alma para a dor...
\end{abstract}

Eu vou sonhando: O meu primeiro amor Abeira-se de mim. Falo-Ihe: flor! É isto sonho, ou é realidade? 


\section{Os miseráveis}

Trazei, ó pobres Mães esfarrapadas,

Ó Mães de emagrecidos, murchos seios, Trazei à mina dor, aos meus anseios, As vossa falas pálidas, veladas.

Ponde na minha fronte as mãos geladas, Nos olhos meus, os vossos olhos cheios De tristeza! Voarão os vãos receios Como bandos de corujas assustadas.

Os infelizes devem caminhar De mãos unidas; pela noite em fora, Uns aos outros se devem amparar:

O mal que nos esmaga e nos dessora Se a um só despedaça sem demora, A muitos é mais leve de arrastar.

\section{Daria a vida}

Daria o meu anel de oiro maciço A quem, nessa hora triste de saudade, Os olhos dela, cheios de piedade, Me mostrasse, por artes de feitiço.

Daria, alegre e tímido, e submisso, A velha lira em que canto a bondade, Se me afirmasse alguém que Ela, em verdade,

Por mim turbou o seu olhar mortiço. 
Mas, àquele que me dissesse, agora, Neste momento, a amada tua está Com o pensamento em ti, porque te adora

Do fundo da sua alma entristecida, Quem isto me afirmasse, oh! Deus, sei lá Se lhe daria até a própria vida?!

\section{Esperança}

Sopre um vento mortal que pelo espaço Vá, um a um, os astros apagando; E a Noite, as negras asas desdobrando, Desça da serra brônzea, passo a passo.

E o velho Mar, rendido de cansaço, Vencido semi-deus, vá agonizando Em doce marulhar, suave e brando, $\mathrm{Na}$ raiz dos vulcões, num choro lasso ...

Erga-se o Mal que os corações aterra Caia, como um sudário, a grande calma Do seu olhar voltado sobre a Terra;

Morra, enfim, quanta Luz a Idéia alcança, Que ainda no seio férvido de uma alma Há de sorrir a estrela da Esperança. 


\section{A minha estrela}

Trazem meus olhos tão desconsolados

Saudades de te ver um riso amigo,

Que já os não levanto, resignados.

Num implorar humilde de mendigo.

E se uma vez os ergo, é que persigo

Outra esperança em teus olhos velados.

Já não aspiro à luz; busco abrigo,

Procuro a sombra, a mãe dos desgraçados.

Destruída a ilusão, senti a vida

Fugir do coração desenganado;

Vi a esperança última perdida,

Como no vento a folha desprendida;

E o homem, na corrente arrebatado, Vogou qual ninho de ave desmanchado.

\section{A dor}

E se adormece a Dor, por um momento.

Num infantil cansaço lagrimoso, Um sonho bom e vago e nebuloso

Envolve friamente o pensamento.

Apareces no plúmbeo firmamento;

O resplendor do teu olhar formoso

Relembra o sol rompendo um céu brumoso,

Pondo consolações no sofrimento. 
És tu, Ventura, és tu! Bem reconheço

Tudo o que tanto amei e não mereço, Ó minha antiga e caprichosa amante!

Ventura, és tu! Mas nunca adormecesse Essa que me consola e fortalece.

Ó minha Dor modesta, ó Dor constante!

\section{Realidade, sonho horrível!}

Fatigam-se as maiores desventuras, $E$ dão momentos de tranqüilidade; Momentos em que a vítima se evade Do seu cárcere horrível de torturas.

Em que se enchem de estrelas as escuras

Longas noites da torva soledade;

E de olhos puros baixa a piedade, O bálsamo que estanca as amarguras

Mas nunca o sofrimento, de cansado, Me desse a vã miragem do impossível, Levantando-me o espírito prostrado.

Porque, sonhar aos beijos no intangível, E ter-se a crua realidade ao lado, É sonho mais pungente e mais horrível. 


\section{Não sei}

Não sei, não sei se o dia de amanhã

Será de dor, ou de felicidade;

Se baixará do céu a tempestade,

Ou se bonança piedosa e sã.

Se há de soprar, ainda, aura pagã

De momentos sem lágrimas; ou se há de

A agonia que pouco a pouco invade

A alma, tornar a vida escura e vã.

Penar assim, a ponto de um momento

De dor, nos parecer bem mais pesado

Que séculos, não há maior tormento.

E quem ousa supor-me no pecado

Porque este peito meu despedaçado

Prefere a morte a tanto sofrimento?

\section{A morte}

A morte é uma grande benfeitora

Que tem, de Deus, essa missão sagrada

De dar repouso á vida atribulada,

De dar liberdade redentora.

Em seu regaço gélido, onde mora

A paz do não sofrer tão almejada, Repousa a vaga essência desmaiada

Da dor da humanidade sofredora. 
Sua mão regelada e piedosa,

Não é a inexorável mão escura

Que empunha a negra fouce tenebrosa.

É nívea mão de amor e de ternura

Que ampara e guarda - eterna mãe bondosa,

Perpetuamente, as almas sem ventura.

\section{Deus}

Dormes, Sombra enigmática? Repousas, Anojado de ver o fero Mal

Cravar, impunemente, o seu punhal

No coração do homem? E não ousas

Desviar os teus olhos para as cousas

Que fermentam no fundo desse urzal

Da alma humana? Será, Deus eternal,

Esse teu sono o último, de lousas?

Sentes jorrar o sangue da inocência,

E vês correr as lágrimas dos tristes?

Não ouves o estertor da consciência

Estrangulada? Indiferente assistes

À acção feroz do crime? Omnipotência!

Esse teu sono é morte! Não existes! 


\section{Sempre adorada}

Desce comigo ao fundo deste horror

De ver, talvez, bem longe ainda o dia, O dia de acordar para a alegria Meu coração turbado pela dor

Desce comigo a este inferno, amor;

À geleira da minha nostalgia, Desce comigo, santa, e avalia O que resta de tanto sonho em flor!

Entre os escombros da felicidade Que, na ilusão gentil de curtos anos, Juntos erguemos numa esperança infinita

Tu verás, no regaço da saudade, Mal ferido do mal dos desenganos Minha alma, doida, a te adorar ainda!

\section{Despedida}

Dirás à minha pobre mãe, coitada!

Que me perdoe não ir, na despedida,

Beijar-lhe a grave fronte tão querida, Beber-lhe o santo olhar, bênção sagrada,

Porque me traz esta alma tão quebrada

A dor inconsolável da partida Que, triste como os que se vão da vida, 
Nem quero ver-Ihe a fronte magoada.

Dirás que levo uma saudade funda Dentro do coração angustiado!

Que a dor é tanta, em suma, tão profunda,

Que me parece, até, ter começado

A morrer, neste lúgubre momento

Em que o navio esfralda asas ao vento.

\section{Partindo}

Triste por te deixar, de manhãzinha

Desci ao porto, asas ao vento, Fomos singrando, sob um céu cinzento, Como, num ar de chuva, uma andorinha.

Olhos na llha eu vi, amiga minha, A pouco e pouco, num decrescimento, Fugir o Lar, perder-se num momento A montanha em que o nosso amor se aninha.

Nada pergunto; nem quero saber Aonde vou: se voltarei sequer; Quanto, em ventura ou lágrimas, me espera.

Apenas sei, ó minha Primavera, Que tu me ficas lagrimosa e triste, E que sem ti a luz já não existe. 


\section{Exilado}

Pensas no que há de mais sombrio e triste;

Terá, destes meus dias, vaga imagem

Soturnos céus - como tu nunca viste

Nunca os deixou o halo duma miragem.

O sol - um sol que só de nome existe

Envolto na algidez e na brumagem

Dum frio - como tu nunca sentiste

Do nosso sol parece a morta imagem.

Imerge o retranzido pensamento

Nas noutes mais escuras, mais glaciais,

Prenhes de raios e de vendavais.

Verás que anos de dor, esse momento

Passado, na saudade e no penar

Longe do sol vital do teu olhar.

\section{$\underline{\text { Triste regresso }}$}

Dentro da claridade

plúmbea da manhã

A llha, sobre o mar, lembra uma catedral.

As nuvens em silêncio imergem devagar

Qual um fumear de incenso 
Num ascetismo intenso,

Num perfume subtil de velha fé cristã

Pelas naves glaciais da brônzea catedral,

A llha, sobre o mar.

E sobem vagamente em lágrimas banhando A dura fronte augusta e grave dos rochedos. Bebe em fundo silêncio a terra fulva, adusta,

A lágrima que cai;

E a nuvem passa, vai,

Numa insondável mágoa imensa rorejando,

Em gélido suor, dos túrbidos rochedos

A dura fronte augusta.

Mas, já da opa cinzenta a llha se desnuda.

Beija-a com fúria o sol, dentes de fogo a comem.

$O$ vento reduziu-Ihe a trapos o lençol.

Emerge, e se acentua,

Do mar, móvel, nua,

Trânsida de tristeza, em uma angústia muda...

E enquanto ao longe as nuvens álgidas se somem

Beija-a com fúria o sol.

Da c'roa do platô à fímbria da leveza

As árvores sem vida estorcem-se de sede.

E o sol - bem como um rei fanático, homicida,

Fustiga -as a matar.

E ri-se ao incendiar

Os ramos - como mãos erguidas de quem reza, $E$ as folhas - como mãos abertas de quem pede,

Das árvores sem vida. 
Em fim, o meu Navio, aos poucos, se aproxima.

Nos dias tristes olhos meus em lágrimas, rebrilha.

A dita de ancorar após mil escarcéus.

$\mathrm{E}$, pois que as nuvens vão

Fugindo na amplidão

Sem que uma gota de água envie lá de cima, Darei à tua sede o pranto - oh minha llha!

Dos tristes olhos meus.

\section{Dia de chuva}

Hoje, que a chuva cai, tamborilando

Nos vidros da janela; e que, estendidas,

Estas várzeas do exílio encandecidas

Verdes relvas as vão alcatifando.

Que o céu, jamais azul; que o ar mais brando

As almas trazem de ilusões vestidas;

Que a esperança engrinalda tantas vidas

Como lírios nos vales rebentando;

Hoje, amor, que a saudade impiedosa

Me traz anuviado o sentimento,

Minha alma triste se ergue dolorosa,

Ferida no rigor da dura sorte

Que lhe nega da paz do lar o alento,

E implora a deus a paz final da morte. 


\section{O sonho}

Quando um dia eu voltar desta viagem, Hei de trazer-te o Sonho cuja ausência Te tem posto pezares na existência, $\mathrm{Na}$ tua vida branda como a aragem.

Se eu lá ficar, porém, nessa miragem

Que acolhe os tristes cheia de clemência Há de voltar a ti a vaga essência Do eterno amor, em pálida romagem.

Minha alma há de voltar a contemplar-te E hás de ouvi-la, num choro doloroso Rogar a Deus de ti jamais a aparte.

E quando soar-te a hora da partida, Como um par, de andorinhas, amoroso, Iremos, juntos, desta à outra vida.

\section{Minha casa}

Ó minha pobre casa! Estância honesta! Minha felicidade inigualada! Quem me dera passar, nesta jornada, À tua sombra, a vida que me resta!

Tudo me fere, tudo me molesta Longe de ti, ó minha pobre amada! 
O sol mais claro não me alegra; nada

Me aquece e me ilumina a fronte mestra!

O meu destino, túrbido, mesquinho

$\mathrm{Na}$ saudade dos olhos siderais

Da companheira que ficou no ninho.

Arrasta-me as visões de dor, mortais;

E penso que talvez neste caminho

Não paro à tua sombra nunca mais!

\section{Saudade}

O muito amor por teus olhos quebrados

De sofrer esta cruel adoração

Por ti, que me traspassa o coração

Nas puas da saudade e dos cuidados.

Estes males da ausência inconsolados

Deram-me a crença da superstição.

E sigo a incerta fé do povo são,

Lendo cartas e sonhos enublados...

E lhes pergunto, ás vezes, se és feliz ...

Se inda te animam esperanças calmas ...

E me sorrio sempre que sorris.

Porque amarrados ambos numa cruz, Embora separados, nossas almas Formam uma só vida, uma só luz. 


\section{Não me pertence}

Talvez eu desse tudo; a imensidade

Do amor, o sonho taciturno e mudo;

Toda a luz da razão, a flor do estudo; O fruto da lição e da verdade.

Daria esta alma louca de saudade;

Daria o meu futuro carrancudo;

A minha carne á dor; daria tudo,

Tudo, menos a minha liberdade!

Sim, essa, à força, só ma podereis

Levar. Não me pertence! Não me veio

Por herança, dos homens nem das leis.

E, se dispor de um bem inalienável

Diante da lei, é crime abominável, Crime maior, será dar o alheio...

\section{$\underline{\text { Crioulas }}$}

A virgem Maria

Pura mãe de Deus

Seria crioula?

Sim; nos sonhos

Meus,

Contemplo-a

Morena, 
Filha de plebeus,

Morena crioula

Rainha dos céus...

Nos seus tristes

Olhos

Boiados de amor,

Há consolações,

Para toda dor

A doce crioula

Pequenina flor

É como a violeta no aroma, na cor.

\section{Hinos}

Revolução ou morte! Eis o nosso dever A paz é, já, um crime; e morte infame, a vida! E se havemos de, - irmãos! ... um dia apodrecer

No ventre desta terra infausta, tam querida;

Se a Pátria santa ao mal temos que ver rendida; Se a aurora do combate um dia há de romper; Se a lágrima, e o suor, e o sangue hão de correr, Avermelhando o mar e a terra envilecida;

E se hão de, num futuro incerto, derramá-los, Filhos do nosso amor ás mãos dos mercenários, Pátria e filhos - irmãos! ... tentemos nós salvá-los!

Morte ou Revolução! Que, não há cobardia Que iguale a de legar a filhos os calvários De nomes com brazões de lodo e vilania! 
